\title{
Direct Exports of Phosphorus from Fertilizers Applied to Grazed Pastures
}

\author{
D. M. Nash, ${ }^{*}$ R. W. McDowell, L. M. Condron, and M. J. McLaughlin
}

\begin{abstract}
Since its discovery in 1669, phosphorus $(P)$ in the form of fertilizer has become an essential input for many agroecosystems. By introducing a concentrated $P$ source, fertilizers increase short-term $\mathrm{P}$ export potential soon after their application and longer-term export potential by increasing soil fertility (legacy P). The 4R concept was developed to help mitigate P exports from the fertilizers that sustain agricultural productivity. This review investigates the factors affecting $P$ exports soon after the application of mineral fertilizers to pasture-based grazing systems and studies quantifying its potential impact in different systems, with an emphasis on Australasia. Initially, P fertilizers and reactions that might affect their short-term $P$ export potential are reviewed, along with $P$ transport pathways, the forms of $P$ exported from grazing systems, factors affecting $P$ mobilization into water, and studies demonstrating the possible short-term effects of fertilizer application on P exports. Using that foundation, we review studies quantifying the short-term impact of fertilizer application in different regions; they show that under poor management, recently applied fertilizer can contribute a considerable proportion (30-80\%) of total farm $\mathrm{P}$ exports in drainage, but when fertilizer is well-managed, that figure is expected to be $<10 \%$. We then use three model systems of varying hydrology that are common to Australasia to demonstrate the principles for selecting fertilizers that are likely to minimize $\mathrm{P}$ exports soon after their application.
\end{abstract}

\section{Core Ideas}

- Fertilizers increase P exports directly or by increasing P cycling. - We review $\mathrm{P}$ pathways and processes relevant to grazing systems.

- Direct fertilizer P exports can be comparatively small ( $<10 \%$ of annual exports).

- Fertilizer selection to minimize P exports in three model systems is demonstrated.
(C) 2019 The Author(s). This is an open access article distributed under the CC BYNC-ND license (http://creativecommons.org/licenses/by-nc-nd/4.0/).

J. Environ. Qual. 48:1380-1396 (2019)

doi:10.2134/jeq2019.02.0085

Received 20 Feb. 2019.

Accepted 15 July 2019.

*Corresponding author (soilandalliedservices@gmail.com).
$\mathrm{P}$ HOSPHORUS (P) is the sixth most abundant element in living organisms. Since its discovery in $1669, \mathrm{P}$ has become an essential input for many agroecosystems (Lun et al., 2018; Sharpley et al., 2018), and P amendments have facilitated our transition to modern urbanized societies. However, the use of $\mathrm{P}$ amendments in agriculture has not been without its challenges. The application of amendments and accumulation of $P$ in agricultural soils (Stutter et al., 2015; Tian et al., 2017) have increased the risk of $\mathrm{P}$ in drainage adversely affecting downstream water resources (ANZECC and ARMCANZ, 2000; Brogan et al., 2001; Cooke et al., 1993; Dodds and Smith, 2016; European Environment Agency, 1998; USEPA, 1996).

In both terrestrial and aquatic systems, organisms extract $\mathrm{P}$ in the form of orthophosphate anions $\left(\mathrm{H}_{2} \mathrm{PO}_{4}^{-} / \mathrm{HPO}_{4}^{2-}\right)$ from water. The total P (TP) concentration needed in soil water for optimum agricultural production is often cited as $>0.2 \mathrm{mg} \mathrm{L}^{-1}$ (Pierzynski et al., 2005). However, a soil water P concentration of $\sim 0.9 \mathrm{mg} \mathrm{L}^{-1}$ was required for maximum pasture productivity in New Zealand field trials (Wheeler and Edmeades, 1995) and concentrations $>>1 \mathrm{mg} \mathrm{L}^{-1}$ have been noted in Australia (Nash et al., 2007; Toifl et al., 2000; Watkins et al., 2012). For freshwater systems, TP concentrations designed to minimize the potential for adverse algal (viz. periphyton) growth are $<0.009$ to $0.07 \mathrm{mg} \mathrm{L}^{-1}$, varying by region or jurisdiction (ANZECC and ARMCANZ, 2018; CCME, 2004; EPA, 2003; Miltner, 2010; Smith and Tran, 2010; Stevenson et al., 2008). Given that some $\mathrm{P}$ is always present in soil water, it follows that transfers from land to water (i.e., $P$ exports) are an inevitable consequence of drainage from terrestrial systems (Haygarth et al., 2005) and streams draining agricultural catchments often suffer "impaired" water quality

In Australasia (i.e., Australia and New Zealand), intensive pasture-based grazing is often the primary land use in catchments with impaired water quality (Dairy Australia, 2019; McDowell et al., 2009a; Meat and Livestock Australia, 2017;

D.M. Nash, School of Agriculture and Food, Faculty of Veterinary and Agricultural Sciences, The Univ. of Melbourne, Parkville, VIC 3010 Australia; D.M. Nash, Soil and Allied Services Pty. Ltd., 1500 Warragul Rd., Strzelecki, VIC 3950 Australia; R.W. McDowell, AgResearch, Lincoln Science Centre, Private Bag 4749, Christchurch 8140 New Zealand; R.W. McDowell and L.M. Condron, Faculty of Agriculture and Life Sciences, P.O. Box 85084, Lincoln Univ., Christchurch 7647 New Zealand; M.J. McLaughlin, School of Agriculture Food and Wine, Waite Research Institute, The Univ. of Adelaide, PMB 1, Glen Osmond, SA 5064 Australia. Assigned to Associate Editor Philip Haygarth.

Abbreviations: DAP, di-ammonium phosphate; DRP, dissolved reactive phosphorus; MAP, mono-ammonium phosphate; $\mathrm{MCP}$, monocalcium phosphate; PR, phosphate rock; SSP, single superphosphate; TDP, total dissolved phosphorus; TP, total phosphorus; TSP, triple superphosphate. 
PricewaterhouseCoopers, 2011; Sinclair Knight Merz, 2011). Although some aspects of water quality may be improving in New Zealand (Larned et al., 2016), P exports from pastures remain a concern (Ballantine and Davies-Colley, 2014; Julian et al., 2017; McDowell et al., 2009a). The New Zealand government has responded to concerns about water quality and use with its National Policy Statement for Freshwater Management (New Zealand Government, 2017). In Australia, both estuarine and freshwater systems suffer impaired water quality from $P$ exports, for example, in Victoria and Western Australia (Birch, 1982; Grayson et al., 2001; Hallows, 1998; Webster et al., 2001). Again, despite remedial efforts (EPA, 1995), water quality in many cases remains a concern (Turral et al., 2017).

Phosphorus exports to water from pasture-based grazing systems can be conveniently divided into "systematic" (i.e., base or background) - and "incidental" (i.e., management)-related components (Haygarth and Jarvis, 1999). Conceptually, background exports are attributable to the production system and ambient conditions. Management decisions and critical incidents can increase $\mathrm{P}$ exports over and above those that would have otherwise occurred and include the application of inorganic fertilizer, spreading of manure, the timing of grazing, and grazing management that affects soil erosion.

Mineral (i.e., inorganic) fertilizers are highly concentrated sources of $\mathrm{P}$ that are often an integral part of pasture-based grazing systems and may contribute directly to "incidental" $\mathrm{P}$ exports soon after their application or indirectly, through increased P cycling (i.e., systematic exports) (McDowell, 2012). Internationally, the $4 \mathrm{R}$ nutrient stewardship concept has been used by the fertilizer industry to guide the development of fertilizer best or good management practices. The $4 \mathrm{R}$ concept is to apply the Right source of nutrients, at the Right rate, at the Right time, and in the Right place (Bruulsema, 2018; Johnston and Bruulsema, 2014). Good management practices consider the individual attributes of each farming system and attempt to optimize nutrient use efficiency and environmental sustainability, while supporting farm profitability. On well-managed farms, practices are adopted that address a range of soil, fertilizer, effluent management, and irrigation issues (Dairy Australia, 2018).

In this review, we address the factors affecting $\mathrm{P}$ exports directly associated with the application of mineral $P$ fertilizers in pasture-based grazing systems, with an emphasis on Australasia. Our objective is to provide a scientific foundation that can underpin the application of the $4 \mathrm{R}$ principles and appropriate fertilizer selection and application strategies to specific farming systems. The discussion of legacy effects (i.e., systematic exports) is outside the scope of this paper. We initially investigate $\mathrm{P}$ fertilizer compounds and formulations commonly applied to pastures and reactions that might affect their short-term $\mathrm{P}$ export potential. Phosphorus transport pathways, the forms of $\mathrm{P}$ exported from grazing systems and the factors affecting $\mathrm{P}$ mobilization into water, are then explored. Using that foundation, studies examining the contribution of recently applied fertilizer to P exports in specific regions are examined. Finally, three model systems with varying hydrology that are common to Australasia are used to demonstrate the principles for fertilizer selection and management that are likely to minimize P exports soon after their application.

\section{Common Phosphatic Fertilizers Applied to Pastures and Their Reactions with Soil}

Some common P compounds in fertilizers and soil are presented in Table 1. Granular inorganic P fertilizers are often surface applied (i.e., broadcast onto pastures) and can be broadly classified as being (i) water soluble, (ii) partially water soluble, or (iii) sparingly soluble (Chien et al., 1989, 2011). The most common water-soluble phosphatic fertilizers are single- and triple-superphosphates, together with mono- and di-ammonium phosphates. Superphosphates are formed by the reaction of an acid with phosphate rock (PR). Where sulfuric acid is used, the resulting fertilizer is a combination of water-soluble monocalcium phosphate (MCP) and gypsum $\left(\mathrm{CaSO}_{4}\right)$ commonly referred to as single superphosphate (SSP). Single superphosphate is the dominant form of $\mathrm{P}$ applied to pastures in Australasia (McDowell et al., 2019). The gypsum in SSP affects the physical properties of the granules and provides sulfur, another essential nutrient for plants. If phosphoric acid, rather than sulfuric acid, is reacted with the PR, a more concentrated MCP fertilizer is produced (triple superphosphate, TSP). Ammonium phosphates are produced by reacting ammonia with phosphoric acid. The products formed depend on the molar ratios of reactants but are commonly monoand di-ammonium phosphate (MAP and DAP). Ammonium phosphates are fully water soluble (Chien et al., 2011).

There are several partially water-soluble P fertilizers, and their chemical properties vary considerably (Chien and Menon, 1995a; Chien et al., 2009). Fertilizers in this group can be made by reacting anhydrous or aqueous ammonia with SSP or TSP, nitric acid with PR, or reactive PR with sulfuric acid or phosphoric acid to form partially acidulated phosphate rock fertilizers (Stephen and Condron, 1986; Yeates and Clarke, 1993). This group also includes fertilizers made by mixing water-soluble compounds, such as SSP, with sparingly soluble compounds such as PR or lime. Sparingly soluble or slow-release P fertilizers include reactive PR (Chien and Menon, 1995b), heat-treated (calcined) $\mathrm{PR}$, and di-calcium phosphate formed by reacting hydrochloric

Table 1. Some common phosphate compounds in fertilizer and soil. $\dagger$

\begin{tabular}{lcccc}
\hline Compound & Formula & Common name (acronym) & Phosphorus concentration & Water solubility \\
\hline Monocalcium phosphate & $\mathrm{Ca}\left(\mathrm{H}_{2} \mathrm{PO}_{4}\right)_{2} \cdot \mathrm{H}_{2} \mathrm{O}$ & $\begin{array}{c}\text { Superphosphate } \\
\text { (SSP/DSP/TSP) }\end{array}$ & $\begin{array}{c}\text { Single, } 9 \% \\
\text { Double, } 18 \%\end{array}$ & Tigh \\
Mono-ammonium phosphate & & & $21 \%$ & $\mathrm{~T}$ \\
Di-ammonium phosphate & $\mathrm{NH}_{4} \mathrm{H}_{2} \mathrm{PO}_{4}$ & MAP & High \\
Di-calcium phosphate & $\left(\mathrm{NH}_{4}\right)_{2} \mathrm{HPO}_{4}$ & DAP & High & Low \\
Hydroxyapatite & $\mathrm{CaHPO}_{4}$ & DCP (anhydrous) & Variable & LCP \\
\hline
\end{tabular}

† Adapted from Nash and Halliwell (1999). 
acid with PR. This paper focuses mainly on the reactions of SSP, DAP, and PR.

A series of precipitation and adsorption reactions explains $\mathrm{P}$ behavior in soil (Barrow, 1983; Barrow, 1989; Holford, 1989). Precipitation-dissolution reactions dominate when there is a large change in the $\mathrm{P}$ concentration, when cation concentrations are high, and when soil $\mathrm{pH}$ is low or high, for example, in the immediate vicinity of a fertilizer granule (Hedley and McLaughlin, 2005). Adsorption-desorption processes dominate when $\mathrm{P}$ concentration changes are small, solution cation concentrations are low, and where micro-surfaces are large, such as in clay soils.

Even in quite dry conditions, water-soluble granular fertilizers absorb water on application to soil (Lawton and Vomocil, 1954). Surface-applied SSP is initially wetted directly from rainfall or irrigation, by capillary uptake of water, and by vapor transfer from the soil or atmosphere due to the hygroscopic nature of the MCP (Williams, 1969). Similar processes would be expected to occur for DAP except that the absence of the calcium sulfate carrier present in SSP would restrict the opportunities for capillarity. The high solubility of DAP would tend to enhance mass flow of soil water to the DAP granule once the wetting process has commenced by establishing a high osmotic gradient in the soil.

Factors affecting the ingress of water vapor into water-soluble fertilizer granules include relative humidity, temperature, and physical properties of the particles themselves such as size, shape, and porosity, and surface oil coatings designed to improve handling (Lawton and Vomocil, 1954; Williams, 1971b). For hygroscopic uptake of water by SSP, a relative humidity $>89 \%$ is generally considered necessary (Williams, 1969) and is exceeded in most field soils (Payne, 1988). Lawton and Vomocil (1954) showed that even at low soil water contents (e.g., 2-4\% w/w), water uptake and movement of phosphate out of SSP granules occurs rapidly (i.e., within hours). Recently, a method to visualize $P$ dissolution and diffusion from fertilizer granules in situ (i.e., in soil) was developed that confirmed that the reaction is fast and virtually complete within $24 \mathrm{~h}$ (Degryse and McLaughlin, 2014).

Coatings applied to water-soluble fertilizer granules affect moisture uptake and $\mathrm{P}$ dissolution. For example, sulfur coatings have been used to slow the release of orthophosphate, thereby increasing P efficiency, and to address other nutrient deficiencies (Engelstad and Terman, 1980). Polymer coatings have also been used in developing controlled release fertilizers (da Cruz et al., 2017; Lambie, 1987; Shaviv and Mikkelsen, 1993; Umesha et al., 2017). Dust suppressants (e.g., oils and waxes) added to fertilizers during manufacture and transport would also be expected to slow water ingress and $\mathrm{P}$ egress from granules, but their effects appear to be small (University of Adelaide Fertilizer Technology Research Centre, unpublished data, 2018).

Monocalcium phosphate is the primary $\mathrm{P}$ component of superphosphate. As water is absorbed, the solution that forms within a superphosphate granule is supersaturated (Williams, 1971a), leading to the precipitation of sparingly soluble di-calcium phosphate dihydrate. Depending on the calcium activity, competing reactions (Bouldin et al., 1960), and complexation of inorganic ions, 20 to $34 \%$ of the TP may be precipitated as di-calcium phosphate dihydrate at the granule site (Lehr et al., 1959). Once dissolution is initiated, the highly acidic solution ( $\mathrm{pH}$ 1.5) diffusing from superphosphate granules dissolves soil minerals, creating a concentrated solution of phosphate, calcium, sulfate, iron, aluminum, and other ions (Lindsay et al., 1959; Lindsay and Stephenson, 1959a, 1959b). As the process continues, vapor transfer and mass flow of water extend the wetted zone and a series of precipitation and adsorption reactions decrease the soil water P concentration (Fig. 1). The importance of these individual reactions depends on, among other things, the $\mathrm{pH}$ and relative proportions (i.e., activities) of the cations in the soil (Bell and Black, 1970a, 1970b; Engelstad and Hellums, 1992; Sample et al., 1980). In higher $\mathrm{pH}$ soils or those rich in calcium, initial dissolution and diffusion of P from SSP (or TSP) granules is retarded due to greater precipitation of di-calcium phosphate dihydrate in and around the granule (Degryse and McLaughlin, 2014; FTRC, 2019; Lombi et al., 2004).

The retention of ammonium phosphates in the soil is likely to be affected by the solution $\mathrm{pH}$ of these compounds, 3.5 for MAP and 8.0 for DAP (Lindsay et al., 1962). When applied to soil, MAP forms reaction products that are initially like those of MCP, di-calcium phosphate dihydrate unless exchangeable magnesium is high. In contrast, DAP forms a range of calcium and magnesium compounds such as calcium di-ammonium diphosphate monohydrate $\left[\mathrm{Ca}\left(\mathrm{NH}_{4}\right)_{2}\left(\mathrm{HPO}_{4}\right)_{2} \cdot \mathrm{H}_{2} \mathrm{O}\right]$, octacalcium hexaphosphate pentahydrate $\left[\mathrm{Ca}_{8} \mathrm{H}_{2}\left(\mathrm{PO}_{4}\right)_{6} \cdot 5 \mathrm{H}_{2} \mathrm{O}\right]$, calcium phosphate dihydrate $\left(\mathrm{CaHPO}_{4} \cdot 2 \mathrm{H}_{2} \mathrm{O}\right)$, and magnesium ammonium phosphate hexahydrate $\left(\mathrm{Mg} \mathrm{NH}_{4} \mathrm{PO}_{4} \cdot 6 \mathrm{H}_{2} \mathrm{O}\right)$ (Bell and Black, 1970a; Moody et al., 1995). Interestingly, while DAP has been shown to increase soil $\mathrm{pH}$ near a granule application site, it decreased soil $\mathrm{pH}$ at the wetting front. In this zone, the acidity, that was attributed to the hydrolysis of water and the precipitation

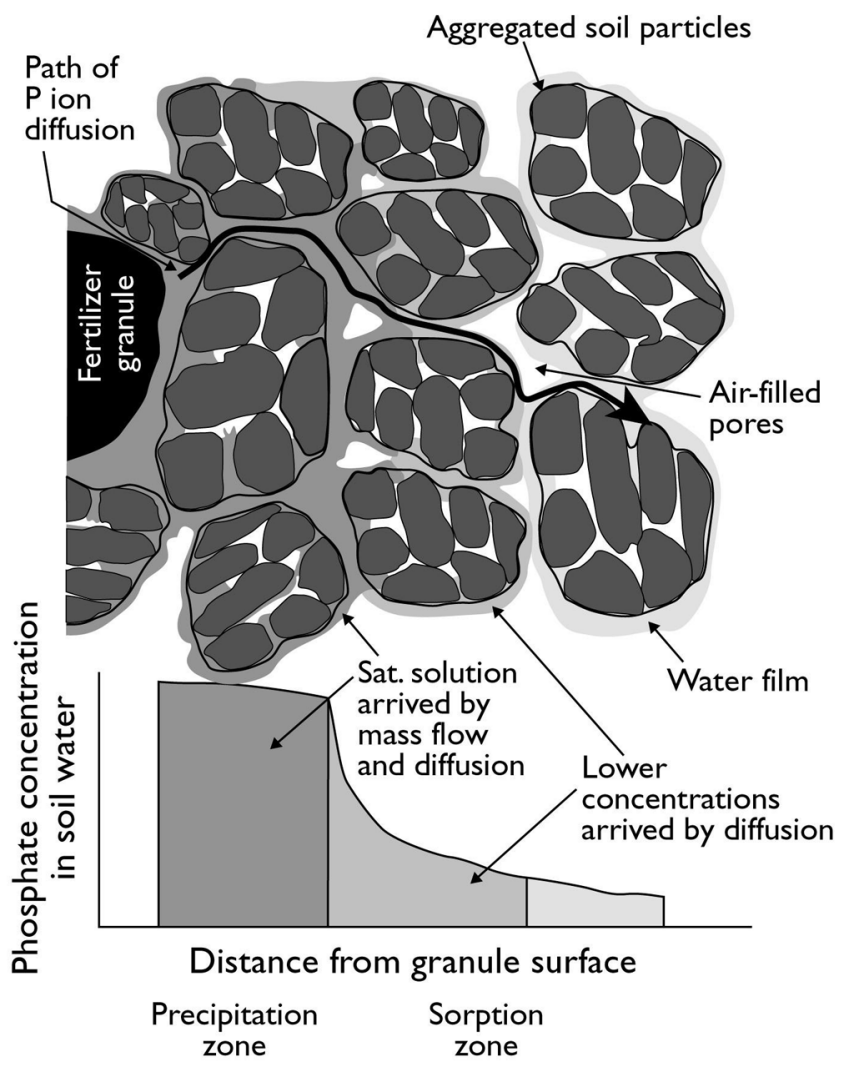

Fig. 1. A diagram representing the movement of phosphate out of fertilizer granules and into soils. Adapted from Hedley and McLaughlin (2005). 
of more acidic compounds than DAP, such as MAP, appeared to dissolve soil components resulting in the precipitation of aluminum phosphates (Sample et al., 1979). Other studies have shown precipitation reactions involving calcium and magnesium can be important (Lombi et al., 2006; Moody et al., 1995). It is noteworthy that nitrification of ammonium from DAP is also likely to lower soil $\mathrm{pH}$ and affect $\mathrm{P}$ reactions in the longer term.

Finely ground reactive PR is primarily used as a fertilizer on acidic soils (Bolan and Hedley, 1997; Hedley and McLaughlin, 2005; Sale et al., 1997a, 1997b). Being sparingly soluble in soil water (equilibrium concentrations $<0.030 \mathrm{mg} \mathrm{P} \mathrm{L}^{-1}$ at $\mathrm{pH}$ 6), the overall availability of the $\mathrm{P}$ from $\mathrm{PR}$ depends on its rate of addition, surface area, mineralogy and chemical reactivity, and the ability of the soil-plant system to enhance dissolution and modify soil pH (Chien et al., 2011; Hedley and McLaughlin, 2005).

The low water solubility of PR lends itself to use in areas with considerable subsurface drainage and poor soil $\mathrm{P}$ sorption, such as Western Australia, where more water soluble fertilizers would not be retained in the root zone. However, a lack of quality rock and poor agronomic effectiveness (Simpson et al., 1997) in areas where the soil $\mathrm{pH}$ is $\geq 6$ and rainfall is $<800 \mathrm{~mm}$ has limited market penetration in Australia. Similarly, use of PR for direct application is a small proportion (4\%) of the New Zealand market (McDowell et al., 2019). Less water soluble superphosphates (e.g., the SuperSR range of products from CSBP Fertilizers and limereverted SSP in New Zealand, often termed dicalcic phosphates), which are basically di-calcium phosphate dihydrate formed by treatment of SSP with lime, are sometimes used, but the agronomic efficiency of these products is usually greater than SSP only in situations where P leaching is significant (i.e., course-textured soils in high-rainfall environments) (Edmeades, 2000). Polymercoated products, while effective in slowing P release from watersoluble products, are generally too expensive for widespread use on pastures and tend to be used more in horticultural production systems on light-textured soils, focused mostly on decreasing losses of nitrogen (Morgan et al., 2009).

\section{Phosphorus Export Pathways in Agricultural Systems}

Waterborne $\mathrm{P}$ exits field soils though several interrelated pathways (Fig. 2) that can be difficult to distinguish.

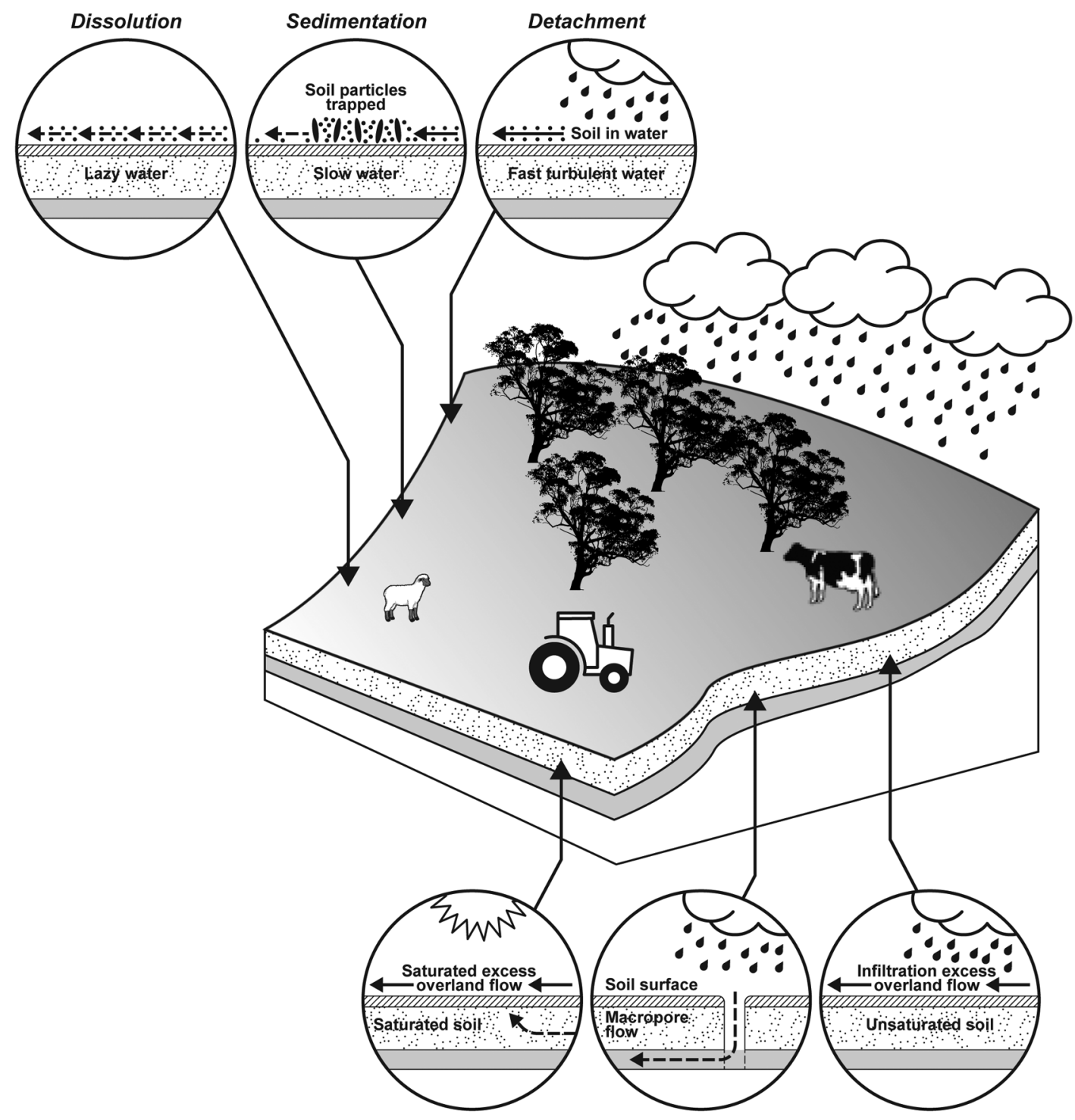

Fig. 2. Hydrology and P mobilization processes at the field scale. Adapted from Nash et al. (2002). 
Infiltration-excess overland flow occurs where water additions exceed vertical drainage (i.e., the infiltration rate and the combined hydraulic conductivity of underlying layers is exceeded) (Emmett, 1978). Infiltration-excess overland flow is affected by factors that alter infiltration behavior such as hydrophobicity, slaking and dispersion, and soil compaction and structural deterioration that affect hydraulic conductivity (Cresswell et al., 1992; Hillel, 1980). Infiltration-excess overland flow tends to increase down slopes as run-on from higher areas increases the hydraulic load, and hence increase the probability of overland flow in receiving areas.

Saturation-excess overland flow is characterized by saturation of the subsoil. Infiltration may be occurring, but at a negligible rate due to the low hydraulic conductivity of the underlying strata. Soils with a permeable A horizon overlying a heavy clay, less-permeable B horizon (Chittleborough, 1992) are prone to such conditions (Cox et al., 2002; Cox and McFarlane, 1995). Saturation-excess overland flow also occurs where groundwater or interflow rises to the surface in discharge zones, often at the break of slope (Gerits et al., 1990; Moore and Foster, 1990; Rulon et al., 1985).

Once entrained, there are limited opportunities for amelioration of $\mathrm{P}$ transported through surface pathways. Sedimentation (Fig. 2) may remove some larger, more dense solids from overland flow, increasing the P concentration (Sharpley, 1980, 1985). However, solution or colloidal P (i.e., $<0.45 \mu \mathrm{m}$ ), collectively termed dissolved $\mathrm{P}$, are unlikely to be affected by such a physical process, and dissolved $\mathrm{P}$ concentrations in overland flow tend to increase with path length (and residence time) (Barlow, 2003; Doody et al., 2006; Nash and Barlow, 2009; Nash et al., 2007).

Matrix flow describes water moving vertically through the soil fabric (Nash and Halliwell, 1999). Matrix flow facilitates adsorption of orthophosphate and deposition of particulate $\mathrm{P}$ (i.e., $>0.45 \mu \mathrm{m}$ ) depending on soil attributes (e.g., soil structure, $\mathrm{P}$ buffering capacity) and the intimacy (i.e., proximity and time) of the drainage and soil contact. Where water drains through stable macropores (e.g., fissures or biopores), P, especially dissolved P, can effectively bypass the soil matrix (Steenhuis et al., 1990).

Interflow describes water moving vertically into the soil without reaching groundwater and then laterally. Interflow can occur at the interface of the $\mathrm{A} / \mathrm{B}$ or $\mathrm{B} / \mathrm{C}$ horizons or in the $\mathrm{A}$ horizon, especially if a compacted layer has formed due to animal traffic. Interflow in the A horizon is difficult to functionally separate from overland flow. Consequently, the latter term will be used to describe them collectively. Like overland flow, interflow accumulates down a slope and, when the incident water and interflow exceed the soil transport capacity (i.e., hydraulic conductivity $\times$ soil thickness), overland flow is likely (Amerman, 1965).

The relative contributions of surface (e.g., overland flow) and subsurface pathways (e.g., interflow) to P exports have been studied at a range of scales (Green and Wang, 2008). Subsurface pathways are favored where substantial macroporosity exists in the subsoil clays (Cox et al., 2000) or water passes through poorly buffered soil (e.g., sand) (Mansell et al., 1977; Ozanne et al., 1961). Subsurface (e.g., tile) drains are the ultimate horizontal macropore facilitating interflow (Gächter et al., 1998; King et al., 2015; Kleinman et al., 2015; Monaghan et al., 2002). In the absence of significant macropore flow, overland flow appears to be the most important pathway for $\mathrm{P}$ exported from well-managed grazing systems in Australia and New Zealand, although evidence exists to show intensive land use has enriched New Zealand groundwater and baseflow P concentrations of some streams (McDowell et al., 2015).

\section{Forms of Phosphorus in Agricultural Drainage and Their Mobilization into Water}

Phosphorus is exported in pasture drainage either as part of a solid, attached to a solid, or as a solute (i.e., dissolved in water). The terms dissolved and particulate are commonly used to define $P$ materials that pass through or are retained by a $0.45-\mu \mathrm{m}$ filter (i.e., about the size of a virus or smaller). It follows that dissolved $\mathrm{P}$ may include some $\mathrm{P}$ attached to, or contained in, colloidal materials (Beckett and Hart, 1993; Haygarth and Sharpley, 2000). Phosphorus forms are further differentiated by their reactivity in an acid-molybdate solution where color formation relies on the presence of orthophosphate (Murphy and Riley, 1962). Due to the hydrolysis of acid-labile P compounds, the test may overestimate orthophosphate concentrations (Broberg and Pettersson, 1988; Burton, 1973; Halliwell et al., 2000a). The most commonly reported forms of $\mathrm{P}$ exported from pastures are TP, total dissolved P (TDP), and dissolved reactive P (DRP).

Phosphorus forms influence the effectiveness of mitigation strategies. For example, vegetative filter strips, commonly termed buffer strips (Hairsine, 1996; Hairsine and Grayson, 1993), use sedimentation to remove particulate $P$ from overland flow but are less effective removing dissolved (i.e., TDP or DRP) forms (Dillaha et al., 1988; Grayson et al., 1994). A well-managed pasture field could itself be considered a "buffer" strip and, in the event of overland flow, be expected to yield predominantly dissolved forms of P (Nash and Murdoch, 1997; Sharpley et al., 1994)

The form in which $\mathrm{P}$ is mobilized also influences its impact on receiving waters. Particulate $P$ (i.e., $>0.45 \mu \mathrm{m}$ ) comprises crystalline $\mathrm{P}$, adsorbed $\mathrm{P}$, and $\mathrm{P}$ in organic matter that require transformation to orthophosphate before they are available to aquatic plants. On the other hand, orthophosphate is often a major component of dissolved P (i.e., $<0.45 \mu \mathrm{m}$ ) and is immediately bio-available (Robinson et al., 1994; Walton and Lee, 1972). The potency of $\mathrm{P}$ exported in a dissolved form as compared to a particulate form is reflected in water quality guidelines that focus on dissolved $\mathrm{P}$ forms in flowing streams and rivers but TP in slow flowing large rivers and lakes and reservoirs (ANZECC and ARMCANZ, 2018; McDowell et al., 2013a, 2013b; Wilcock et al., 2007).

The mobilization of particulate $\mathrm{P}$ (i.e., solids) is primarily a physical process that commences with detachment of fine particles (sediments) and associated P from aggregates and other soil materials. The term erosion is commonly used to refer to a process whereby mobilization (i.e., detachment) is followed by entrainment of particulate materials in flowing water. Detachment is facilitated by physical processes including raindrop impact, cultivation, cattle treading damage, and flowing water and by physicochemical processes such as slaking and dispersion (Davies and Payne, 1988; Leeper and Uren, 1997). The capacity of water to transport particulate materials is related to the kinetic energy of 
the water (Shainberg et al., 1994). Factors that increase water velocity (e.g., slope) and turbulence (e.g., obstructions) generally increase detachment and transport rates. Erosion processes are well reviewed elsewhere (Kelley, 1983; Smith and Wischmeier, 1962; Wischmeier and Smith, 1978).

The processes controlling mobilization of dissolved $\mathrm{P}$ are more complex, having both physical and chemical components. Factors that might be expected to affect dissolved P mobilization include the availability of soluble $\mathrm{P}$ sources, the sorption characteristics of the soil matrix in the immediate vicinity of $\mathrm{P}$ sources, the presence or absence of chelating agents or substances that may block adsorption sites (Guppy et al., 2005a, 2005b), and "residence time," the time available for soil and water interaction (Pierzynski et al., 2005). However, the strongest evidence regarding the nature of dissolved P mobilization comes from field-scale observations.

When rain falls, or irrigation water is applied to a pasturebased grazing system, it washes over and through vegetation and onto the soil surface. It is on the soil surface that animals defecate, fertilizers are often applied, and detritus from pasture plants and supplementary feed falls. It is also here, in the spongy mixture of inorganic and organic materials at the surface, that $\mathrm{P}$ mobilization is initiated. It follows that live plants and their detritus can be important sources of P (Sharpley, 1981; Toor et al., 2003). Relationships between the tannin color, dissolved organic carbon, and TDP in overland flow tentatively support that proposition (Halliwell et al., 2000b; Nash et al., 2014), as do studies measuring $\mathrm{P}$, often orthophosphate, extracted from "hayed-off" Phalaris, clover (Trifolium spp.), and other plants (Bromfield and Jones, 1972; Jones and Bromfield, 1969; Noack et al., 2012).

Mixing layer models have been used to describe contaminant mobilization (Shi et al., 2011). They are particularly useful for conceptualizing mobilization of contaminants into overland flow. These models often comprise (i) a mixing layer near the surface from which materials (e.g., P) are rapidly mobilized (Process 1) and (ii) a slower mobilization process dominated by diffusion and hydraulic dispersion (i.e., mechanical mixing by velocity variations at the microscopic level during advective transport) that transfers materials into the mixing layer from below and facilitates $\mathrm{P}$ egress from aggregates or detrital material in the mixing layer (Process 2). The depth to which soil and water mix is a critical parameter as it determines the quantity of $P$ available for rapid mobilization.

Tracer studies using simulated rainfall $\left(68 \mathrm{~mm} \mathrm{~h}^{-1}\right)$ and repacked bare soil in boxes suggest the "effective depth of interaction," a composite of the mixing depth and soil supplying $P$ into that region from below, can be $<20 \mathrm{~mm}$ (Ahuja and Lehman, 1983), with extraction efficiency declining exponentially with depth (Snyder and Woolhiser, 1985). In similarly conducted model studies using ${ }^{32} \mathrm{P}$, the mixing layer (i.e., the layer where the mobilization of $\mathrm{P}$ was consistent with that of the soil surface) for simulated rainfall $\left(65 \mathrm{~mm} \mathrm{~h}^{-1}\right)$ was $<3 \mathrm{~mm}$ (Ahuja et al., 1981).
If the depth of the mixing layer relates to rapid mobilization, then a mixing layer of $\sim 3 \mathrm{~mm}$ might be expected for $P$ in many well-managed pastures. Natural rainfall is often less intense than that used in simulation studies, and the pasture canopy and detrital material would be expected to intercept raindrops, lowering the kinetic energy available for aggregate disruption and mixing. On the other hand, surface perturbations from animal traffic may well increase the "apparent" (i.e., effective) depth of interaction by increasing the soil surface area and decreasing soil stability (Drewry, 2006; Drewry et al., 2008; Greenwood and McKenzie, 2001).

Field-scale processes that are difficult to simulate are also likely to affect the resupply of $\mathrm{P}$ into the mixing layer (Process 2). Infiltrating water can transport $P$ away from the mixing layer, while return flow may do the opposite (Fig. 3). Depending on the field-scale hydrology, these may negate or overwhelm the effects of diffusion and hydraulic dispersion. It follows that resupply of $\mathrm{P}$ into the mixing layer can be influenced by soil water content, pore-size distribution and most important, soil infiltration characteristics (Ahuja, 1990; Kleinman et al., 2006; Snyder and Woolhiser, 1985; Vadas et al., 2008).

A mixing layer model is consistent with increasing wetting front TDP with path length in border-check (also called border-dyke) irrigation bays noted previously (Nash et al., 2007) and flume studies (Barlow, 2003; Doody et al., 2006). In border-check irrigation, high initial infiltration rates occur at the comparatively dry wetting front. But behind the wetting front, infiltration rates rapidly decline and overland flow increases (Nash and Barlow, 2009). Water samples, which by necessity are recovered from just behind the true wetting front, most probably have $\mathrm{P}$ concentrations that reflect initial $\mathrm{P}$ mobilization from the mixing layer and therefore increase with distance down the bay. In flume studies, and in the absence of infiltration, increasing $\mathrm{P}$ concentrations with time are likely to reflect $\mathrm{P}$ transported into the mixing layer by diffusion and hydraulic dispersion.

A mixing model also helps explain relationships between $\mathrm{P}$ concentrations and stormflow. Poor relationships are often observed between overland flow volume and flow-weighted P concentrations for individual storms (Nash et al., 2000, 2005; Owens and Shipitalo, 2006). Mobilization of P from the mixing layer (Process 1) early in a storm would be expected to rapidly give way to slower mobilization (Process 2 ) as the storm progresses. It follows that between-storm variation in flow-weighted $P$ concentrations would more reflect event duration than total

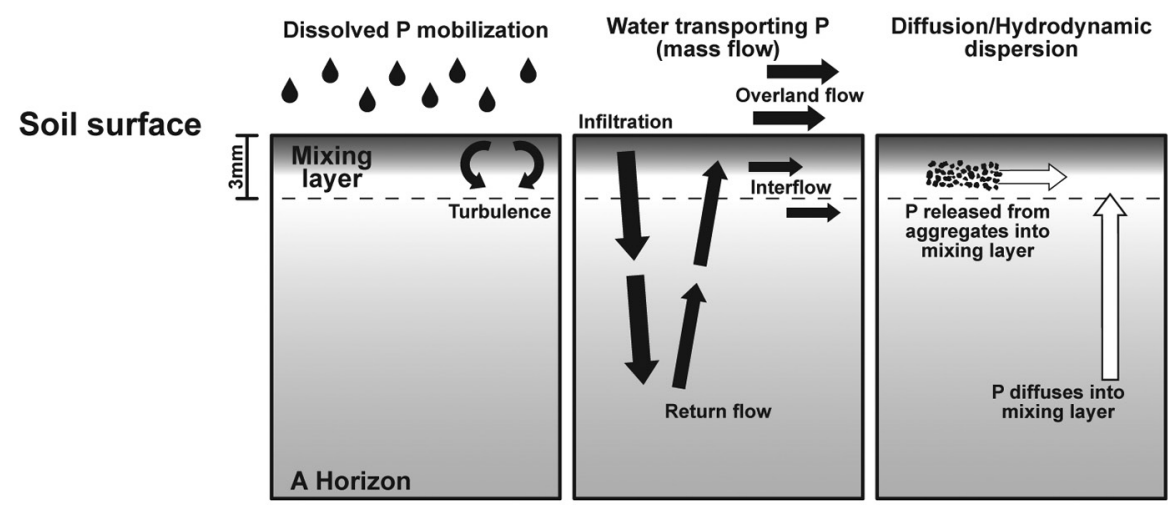

Fig. 3. Field-scale processes contributing to dissolved $\mathrm{P}$ mobilization. 
flow volume. It also follows that within-storm $\mathrm{P}$ concentrations would tend to be inversely proportional to flow rate due to dilution. These attributes were exemplified in a study of rainfallinduced overland flow at Darnum in southeastern Australia comprising 61 storms over 7 yr (1994-2000). Flow-weighted $\mathrm{TP}$ concentrations for individual runoff events were unrelated to the flow volume (Nash et al., 2005). However, in many instances within-storm TP concentrations were related to the overland flow rate at the time (Fig. 4) (Nash and Murdoch, 1997). At that site, TDP comprised $93 \%$ of TP. Such studies emphasize the importance of time-dependent processes to field-scale P exports.

\section{Quantifying the Short-term Impacts of Fertilizer on Phosphorus Exports}

Numerous authors have investigated the effects of fertilizer application on P exports (Hart et al., 2004). Some such studies are summarized in Table 2. Rarely have these studies generalized the within-year (i.e., between-storm) variation associated with specific activities, such as fertilizer application, or the long-term trends in background (i.e., base or systematic) P exports. Most of these studies have demonstrated that it is possible for recently applied fertilizer to overwhelm other P sources. However, from a catchment management perspective the key question is not what is "possible," but rather what is "probable."

A conceptual model with background and management components has been used to investigate the effects of surfaceapplied fertilizer on a grazed pasture (1.8 ha) at Darnum in the Gippsland region of southeastern Australia (Eq. [1]) (Nash et al., 2000):

$\mathrm{TP}=k_{i} \times \mathrm{DAF}^{-0.476} \times \mathrm{DAG}^{-0.241} \times \mathrm{RUNOFF}^{-0.105}$

where TP is the flow-weighted mean total $\mathrm{P}$ concentration for the event $\left(\mathrm{mg} \mathrm{TP} \mathrm{L}^{-1}\right)$; DAF is the interval (d) between fertilizer application and overland flow; DAG is the interval $(\mathrm{d})$ between grazing and overland flow; RUNOFF is the total overland flow volume (L) for the event; and $k_{i}$ is a constant relating to year (i). While A/B-horizon interflow existed at the site, overland flow was primarily responsible for P exports with DRP being 93\% of TP. A multiplicative model (Eq. [1]) using data from 34 storms over 3 yr explained $68 \%$ of the variance (adjusted $R^{2}$ ) in

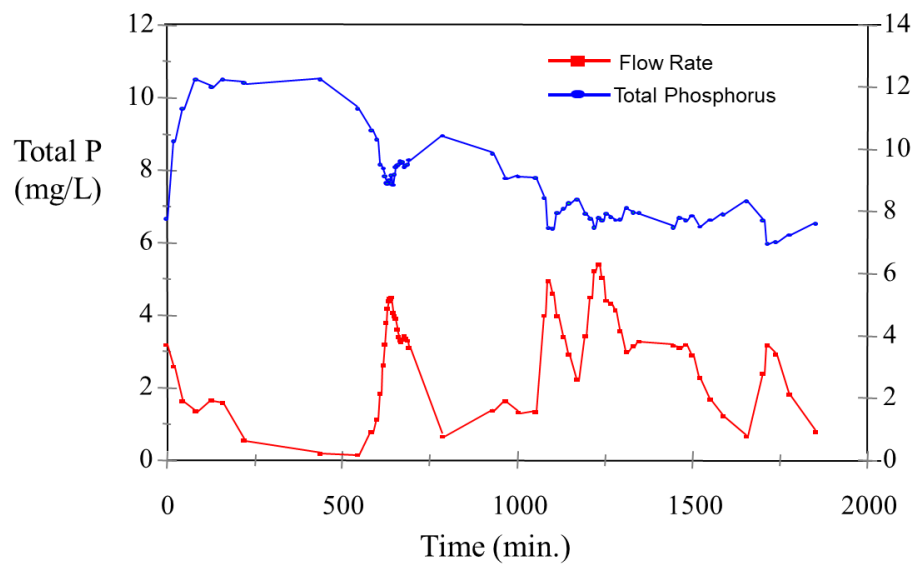

Fig. 4. Within-storm variation in total $P$ concentration and flow from a field in the Darnum region of West Gippsland, Australia, on 6 Nov. 1994. Source: Nash and Murdoch (1997). $\ln$ (flow-weighted TP). The interval between fertilizer application and overland flow was inversely related to TP $(P<0.001)$ and accounted for $50.6 \%$ (adjusted $R^{2}$ ) of the variance. The interval between grazing and overland flow, although significant, was less strongly correlated to TP. In keeping with a plot-scale study (Dougherty et al., 2008), the initial half-life of fertilizer impact (i.e., the number of days since fertilizing to decrease the TP concentration by half) was estimated to be $4.3 \mathrm{~d}$, with $95 \%$ confidence interval of 3.1 to $8.0 \mathrm{~d}$. There was no consistent effect of total storm flow on TP.

Equation [1] is empirical, developed to describe the data without necessarily reflecting the physical processes involved. While mathematically correct, it implies that the factors affecting flow-weighted $\mathrm{P}$ concentrations are inappropriately interrelated. For example, the effects of fertilizer application decay with time after grazing (e.g., if grazing occurs a long time before fertilizer application and subsequent overland flow, then the effects of fertilizer application are minimized)

In a similar study using broiler litter applied to pasture in the United States, a more conceptually sound, additive model was used. The model, which incorporated terms for background (i.e., base) and management components, explained $70 \%$ of the variance in DRP concentrations in overland flow (Pierson et al., 2001). Again, time between $P$ application and overland flow was the most influential term in the model, explaining $32 \%$ of the total variation.

A similarly conceptually sound, additive model (Eq. [2]) was used to investigate 124 events (>2500 L), 61 from Darnum (1994-2000) and 63 from border-check (i.e., flood) irrigated pastures at the Macalister Research Farm (1999-2000) in central Gippsland (Nash et al., 2005):

$$
\begin{aligned}
\mathrm{TP}_{i j}= & (\text { Initial concentration of P in added water })+ \\
& \frac{(\mathrm{P} \text { from grazing })+(\mathrm{P} \text { from fertilizer })+(\text { Background } \mathrm{P})}{\text { Volume }}
\end{aligned}
$$

where TP is the TP concentration $\left(\mathrm{mg} \mathrm{TP} \mathrm{L}^{-1}\right)$ in overland flow for that event. It is noteworthy that in keeping with the processes leading to dissolved $\mathrm{P}$ mobilization presented earlier, there is assumed to be no interaction between fertilizer application and grazing. The relationship between overland flow volume and flow-weighted TP was again insignificant, as was the initial P concentration in added water. Concentrations in overland flow varied from 1.4 to $110.0 \mathrm{mg} \mathrm{TP} \mathrm{L}^{-1}$ at Darnum and 1.6 to $103.5 \mathrm{mg} \mathrm{TP} \mathrm{L}^{-1}$ at the Macalister Research Farm. The highest $\mathrm{P}$ concentrations occurred when fertilizer application and overland flow coincided.

The flow-weighted annual $P$ concentrations varied between 3.3 and $28.2 \mathrm{mg} \mathrm{TP} \mathrm{L}^{-1}$ for Darnum and 6.2 and $31.5 \mathrm{mg} \mathrm{TP} \mathrm{L}^{-1}$ for the Macalister Research Farm. The models explained 61 and $70 \%$ of the variation in log-transformed TP for Darnum and the Macalister Research Farm, respectively, with the base and management factors all highly significant (Fig. $5)$. The fertilizer half-lives were slightly shorter than the previous Darnum study, $2.9 \mathrm{~d}$ (95\% confidence interval 1.7-9.3 d) for Darnum and $3.9 \mathrm{~d}$ ( $95 \%$ confidence interval 2.8-6.1 d) for Macalister Research Farm. Even though soil fertility at the Darnum site 
Table 2. Selected studies investigating the effects of inorganic fertilizer application on P exports from grassed systems.

\begin{tabular}{|c|c|c|c|c|c|c|}
\hline Study location & $\begin{array}{c}\text { Fertilizer type and } \\
\text { application rate } \dagger\end{array}$ & $\begin{array}{c}\text { Study } \\
\text { area (ha) }\end{array}$ & Experimental conditions & $\begin{array}{c}\text { Phosphorus } \\
\text { concentration range } \neq\end{array}$ & $\begin{array}{c}\text { Phosphorus } \\
\text { export‡ }\end{array}$ & Source \\
\hline New Zealand & $\begin{array}{l}\text { Various fertilizers and } \\
\text { rates were applied }\end{array}$ & $\begin{array}{c}248 \\
38 \\
1.44\end{array}$ & $\begin{array}{l}\text { Natural rainfall, grassed } \\
\text { hill country pasture with } \\
\text { streamflow monitoring } \\
\text { in nested design }\end{array}$ & $\begin{array}{c}0.003-0.051 \mathrm{mg} \mathrm{TDP} \mathrm{L}^{-1} \\
0.007-0.20 \mathrm{mg} \text { TDP } \mathrm{L}^{-1} \\
0.026-1.49 \mathrm{mg} \text { TDP } \\
\mathrm{L}^{-1} \text { for respective } \\
\text { catchments }\end{array}$ & - & McColl, 1978 \\
\hline New Zealand & $\begin{array}{l}\text { SSP aerially applied at } 30 \\
\mathrm{~kg} \mathrm{P} \mathrm{ha-1}^{-1}\end{array}$ & 20 & $\begin{array}{l}\text { Natural rainfall on pasture } \\
\text { with streamflow gauging }\end{array}$ & $\begin{array}{l}<0.5-1.56 \mathrm{mg} \mathrm{TPP} \mathrm{L}^{-1} \\
<0.05-9.83 \mathrm{mg} \mathrm{DRP} \mathrm{L}^{-1}\end{array}$ & $\begin{array}{l}0.6 \mathrm{~kg} \mathrm{DRP} \mathrm{ha}^{-1} \\
1.59 \mathrm{~kg} \mathrm{TP} \mathrm{ha}^{-1} \\
\text { attributed to fertilizer }\end{array}$ & $\begin{array}{c}\text { Sharpley and Syers, } \\
1979\end{array}$ \\
\hline New Zealand & $\begin{array}{c}\text { SSP applied above } \\
\text { collectors at } \sim 50 \mathrm{~kg} \mathrm{P} \\
\text { ha }^{-1}\end{array}$ & $\begin{array}{l}\text { Within } \\
\text { paddock } \\
\text { samplers }\end{array}$ & $\begin{array}{l}\text { Natural rainfall on hill } \\
\text { country pasture with } \\
\text { overland flow monitoring }\end{array}$ & $\begin{array}{l}1.2-1.46 \mathrm{mg} \mathrm{TP} \mathrm{L}^{-1}, \\
\text { ungrazed } \\
1.16-25.8 \mathrm{mg} \mathrm{TP} \mathrm{L}^{-1} \\
\text { grazed }\end{array}$ & - & $\begin{array}{c}\text { McColl and Gibson, } \\
1979\end{array}$ \\
\hline USA & $\begin{array}{l}\text { Ammonium phosphate } \\
\text { applied at } 75 \mathrm{~kg} \mathrm{P} \mathrm{ha-1}^{-1}\end{array}$ & $\begin{array}{c}9.6 \\
11 \\
7.8 \\
11.1\end{array}$ & $\begin{array}{l}\text { Natural rainfall on pasture } \\
\text { in paired catchments }\end{array}$ & $\begin{array}{c}0.025-6.49 \mathrm{mg} \mathrm{TDP} \mathrm{L}^{-1} \\
0.44-8.21 \mathrm{mg} \mathrm{TP} \mathrm{L}^{-1}\end{array}$ & $\begin{array}{l}3.3 \mathrm{~kg} \mathrm{TDP} \mathrm{ha}^{-1} \\
4.1 \mathrm{~kg} \text { TP ha-1 } \\
\text { attributed to fertilizer }\end{array}$ & $\begin{array}{c}\text { Olness et al., } \\
1980\end{array}$ \\
\hline New Zealand & $\begin{array}{l}\text { SSP in liquid and solid } \\
\text { forms applied at } 50 \mathrm{~kg} \\
\mathrm{P} \mathrm{ha}^{-1}\end{array}$ & $\begin{array}{l}0.0055 \\
0.0055 \\
0.0041\end{array}$ & $\begin{array}{l}\text { Natural rainfall on } \\
\text { permanent pasture plots } \\
\text { measuring overland flow }\end{array}$ & $\begin{array}{l}0.2-4.1 \mathrm{mg} \mathrm{DRP} \mathrm{L}^{-1} \\
0.3-4.3 \mathrm{mg} \mathrm{TPP} \mathrm{L}^{-1}\end{array}$ & $\begin{array}{l}1.4 \mathrm{~kg} \mathrm{DRP} \mathrm{ha}{ }^{-1} \text { and } 2.9 \\
\mathrm{~kg} \mathrm{TP} \text { attributed to solid } \\
\mathrm{SSP} \text { and } 0.5 \mathrm{mg} \mathrm{DRP} \mathrm{ha}^{-1} \\
\text { and } 1.2 \mathrm{~kg} \mathrm{TP} \mathrm{ha}^{-1} \text { to } \\
\text { liquid SSP annually }\end{array}$ & $\begin{array}{l}\text { Sharpley and Syers, } \\
1983\end{array}$ \\
\hline Australia & $\begin{array}{l}\text { SSP applied at 0, 100, } \\
200, \text { and } 400 \mathrm{~kg} \mathrm{P} \mathrm{ha}^{-1}\end{array}$ & 0.004 & $\begin{array}{l}\text { Natural rainfall on } \\
\text { permanent pasture plots } \\
\text { measuring overland flow }\end{array}$ & $\begin{array}{l}0.7-62.9 \mathrm{mg} \mathrm{DRP} \mathrm{L}{ }^{-1} \\
1.0-66.9 \mathrm{mg} \mathrm{TP} \mathrm{L}^{-1}\end{array}$ & $\begin{array}{l}<0.1-0.40 \mathrm{~kg} \mathrm{DRP} \mathrm{ha}^{-1} \\
<0.2-0.45 \mathrm{~kg} \mathrm{TP} \mathrm{ha}^{-1}\end{array}$ & $\begin{array}{c}\text { Greenhill et al., } \\
\text { 1983a, 1983b, 1983c }\end{array}$ \\
\hline New Zealand & $\begin{array}{l}\text { Mainly superphosphate } \\
\text { applied at } 11 \\
\text { and } 64 \mathrm{~kg} \mathrm{P} \mathrm{ha}^{-1}\end{array}$ & $0.13-1.53$ & $\begin{array}{c}\text { Natural rainfall on hill } \\
\text { country pasture measuring } \\
\text { overland flow }\end{array}$ & - & $\begin{array}{c}0.66-1.95 \mathrm{~kg} \mathrm{TP} \mathrm{ha}^{-1} \\
\text { annually }\end{array}$ & $\begin{array}{l}\text { Lambert et al., } \\
1985\end{array}$ \\
\hline USA & $\begin{array}{l}\text { Commercially available } \\
\text { inorganic fertilizer } \\
\text { blend surface applied or } \\
\text { incorporated } \\
\text { at } 87 \mathrm{~kg} \mathrm{P} \mathrm{ha}^{-1}\end{array}$ & 0.0009 & $\begin{array}{l}\text { Simulated rainfall ( } 50 \mathrm{~mm} \\
\mathrm{~h}^{-1} \text {, applied for } 30 \text { min after } \\
\text { drainage commenced) with } \\
\text { fescue pasture on non- } \\
\text { incorporation treatments } \\
\text { measuring overland flow }\end{array}$ & 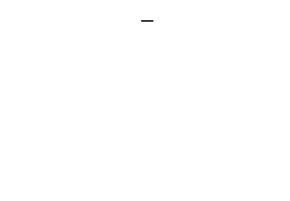 & $\begin{array}{l}1.5 \mathrm{~kg} \mathrm{DRP} \mathrm{ha}^{-1} \\
1.7 \mathrm{~kg} \mathrm{TP} \mathrm{ha}^{-1}\end{array}$ & $\begin{array}{c}\text { Nichols et al., } \\
1994\end{array}$ \\
\hline Australia & $\begin{array}{l}\text { SSP applied at 0, 22, } \\
44,66,88 \mathrm{~kg} \mathrm{P} \mathrm{ha}^{-1}\end{array}$ & 0.024 & $\begin{array}{l}\text { Border-check irrigation } \\
\text { of white clover-ryegrass } \\
\text { pastures measuring } \\
\text { tailwater overland flow }\end{array}$ & $\begin{array}{l}\sim<0.5-119 \mathrm{mg} \mathrm{DRP} \mathrm{L}^{-1} \\
\sim<0.5-121 \mathrm{mg} \mathrm{TP} \mathrm{L}^{-1}\end{array}$ & $\sim 7.7-15 \mathrm{~kg} \mathrm{TP} \mathrm{ha}^{-1}$ & Austin et al., 1996 \\
\hline UK & $\begin{array}{c}\text { TSP applied at } 16 \mathrm{~kg} \mathrm{P} \\
\mathrm{ha}^{-1}\end{array}$ & 1 & $\begin{array}{l}\text { Natural rainfall on ryegrass } \\
\text { pasture measuring } \\
\text { overland flow to } \\
300 \mathrm{~mm} \text { soil depth }\end{array}$ & $\begin{array}{l}<0.02-1.30 \mathrm{mg} \mathrm{DRP} \mathrm{L}^{-1} \\
<0.03-1.77 \mathrm{mg} \mathrm{TP} \mathrm{L}^{-1}\end{array}$ & 3 kg TP ha-1 annually & $\begin{array}{c}\text { Haygarth and Jarvis, } \\
1997\end{array}$ \\
\hline UK & $\begin{array}{l}\text { DAP applied at } 150 \mathrm{~kg} \\
\mathrm{P} \mathrm{ha}^{-1}\end{array}$ & 0.015 & $\begin{array}{l}\text { Simulated rainfall }(22 \mathrm{~mm} \\
\mathrm{h}^{-1} \text { ) applied to hillslope } \\
\text { ungrazed permanent } \\
\text { pasture plots for } 35 \text { min on } \\
4 \text { consecutive days }\end{array}$ & $\begin{array}{l}15.3 \text { mean } \mathrm{mg} \mathrm{TP} \mathrm{L}^{-1} \text { for } \\
\text { fertilized plots }\end{array}$ & $\begin{array}{l}\sim 2.5 \mathrm{~kg} \mathrm{DRP} \mathrm{ha}^{-1} \\
\sim 3.6 \mathrm{~kg} \mathrm{TP} \mathrm{ha}^{-1}\end{array}$ & $\begin{array}{l}\text { Heathwaite et al., } \\
1998\end{array}$ \\
\hline UK & $\begin{array}{l}\text { TSP applied at } 29 \mathrm{~kg} \mathrm{P} \\
\mathrm{ha}^{-1}\end{array}$ & 0.003 & $\begin{array}{l}\text { Natural rainfall ( } 48.8 \mathrm{~mm} \\
\text { in } 169 \mathrm{~h} \text { with rain intensity } \\
\leq 3 \mathrm{~mm} \mathrm{~h}^{-1} \text { ) on perennial } \\
\text { ryegrass, cattle and sheep } \\
\text { grazed pasture, causing } 46 \\
\text { mm drainage measuring } \\
\text { overland flow to } \sim 300 \mathrm{~mm}\end{array}$ & $<0.10-11.0 \mathrm{mg} \mathrm{TP} \mathrm{L}^{-1}$ & $\begin{array}{c}1.8 \mathrm{~kg} \mathrm{TP} \mathrm{ha}^{-1} \text { of which } \\
\sim 70 \% \text { was DRP during } \\
\text { the } 7-\mathrm{d} \text { experimental } \\
\text { period }\end{array}$ & Preedy et al., 2001 \\
\hline Australia & $\begin{array}{l}\text { SSP applied at } \\
44 \mathrm{~kg} \mathrm{P} \mathrm{ha}^{-1}\end{array}$ & 0.024 & $\begin{array}{l}\text { Border-check irrigation } \\
\text { of white clover-ryegrass } \\
\text { pastures measuring } \\
\text { tailwater overland flow }\end{array}$ & $\begin{array}{l}0.45 \text { to } \sim 89 \mathrm{mg} \mathrm{DRP} \mathrm{L}^{-1} \\
0.35-98 \mathrm{mg} \mathrm{TP} \mathrm{L}^{-1}\end{array}$ & $\begin{array}{c}2.6-15 \mathrm{~kg} \mathrm{TP} \mathrm{ha}^{-1} \text { over } 3 \\
\text { irrigations }\end{array}$ & $\begin{array}{l}\text { Bush and Austin, } \\
2001\end{array}$ \\
\hline USA & $\begin{array}{c}\text { Inorganic fertilizer } \\
\text { assumed to have only } \\
\text { soluble } \mathrm{P} \text { applied at } 25 \\
\text { and } 50 \mathrm{~kg} \mathrm{P} \mathrm{ha}^{-1}\end{array}$ & 0.0006 & $\begin{array}{c}\text { Natural rainfall of common } \\
\text { Bermudagrass measuring } \\
\text { overland flow }\end{array}$ & $1.1-30 \mathrm{mg} \mathrm{DRP} \mathrm{L^{-1 }}$ & $\begin{array}{l}\sim 8.5 \mathrm{~kg} \mathrm{P} \mathrm{ha}^{-1} \text { lost in } 8 \\
\text { monitored runoff events } \\
\text { and plant uptake }\end{array}$ & $\begin{array}{l}\text { Gaudreau et al., } \\
2002\end{array}$ \\
\hline New Zealand & $\begin{array}{c}\text { SSP applied at } \sim 17,22, \text { or } \\
33 \mathrm{~kg} \mathrm{P} \mathrm{ha}^{-1} \text { and reactive } \\
\text { PR at } 175 \mathrm{~kg} \mathrm{ha}^{-1}\end{array}$ & 0.000021 & $\begin{array}{l}\text { Simulated rainfall ( } 15 \mathrm{~mm} \\
\mathrm{~h}^{-1} \text { with samples taken } \\
\text { for } 1 \mathrm{~h} \text { after flow started) } \\
\text { on intact turfs of varying } \\
\text { fertilizer history measuring } \\
\text { overland flow }\end{array}$ & $\begin{array}{l}0.01-5.40 \mathrm{mg} \mathrm{DRP} \mathrm{L}^{-1} \\
0.17-6.98 \mathrm{mg} \mathrm{TP} \mathrm{L}^{-1}\end{array}$ & - & $\begin{array}{l}\text { McDowell et al., } \\
2003\end{array}$ \\
\hline
\end{tabular}


Table 2. Continued.

\begin{tabular}{|c|c|c|c|c|c|c|}
\hline Study location & $\begin{array}{l}\text { Fertilizer type and } \\
\text { application rate }\end{array}$ & $\begin{array}{c}\text { Study } \\
\text { area (ha) }\end{array}$ & Experimental conditions & $\begin{array}{c}\text { Phosphorus } \\
\text { concentration range } \neq\end{array}$ & $\begin{array}{l}\text { Phosphorus } \\
\text { export‡ }\end{array}$ & Source \\
\hline USA & $\begin{array}{l}\text { SSP applied a } 0,22,66, \\
\text { and } 110 \mathrm{~kg} \mathrm{P} \mathrm{ha}^{-1}\end{array}$ & 0.0004 & $\begin{array}{l}\text { Simulated rainfall ( } 76 \mathrm{~mm} \\
\mathrm{~h}^{-1} \text { applied for } 30 \mathrm{~min} \text { after } \\
\text { drainage commenced) on } \\
\text { field plots }\end{array}$ & $\begin{array}{l}0.18 \text { to } \sim 5.5 \mathrm{mg} \mathrm{DRP} \mathrm{L}^{-1} \\
1.60 \text { to } \sim 13 \mathrm{mg} \mathrm{TP} \mathrm{L}^{-1}\end{array}$ & $\begin{array}{c}0.03 \text { to } \sim 1.1 \mathrm{~kg} \mathrm{DRP} \mathrm{ha}^{-1} \\
0.26 \text { to } \sim 2.0 \mathrm{~kg} \mathrm{TP} \mathrm{ha}^{-1}\end{array}$ & $\begin{array}{l}\text { Tarkalson and } \\
\text { Mikkelsen, } 2004\end{array}$ \\
\hline Australia & $\begin{array}{c}\text { SSP and DAP both } \\
\text { surface-applied at } 50 \mathrm{~kg} \\
\mathrm{P} \mathrm{ha}^{-1}\end{array}$ & $\sim 1.1$ & $\begin{array}{l}\text { Border-check irrigation } \\
\text { of white clover-ryegrass } \\
\text { pastures measuring } \\
\text { tailwater overland flow for } \\
\text { the rainfall study and on- } \\
\text { bay wetting front sampling } \\
\text { for the irrigation study }\end{array}$ & 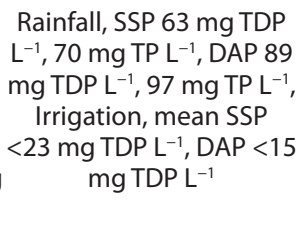 & $\begin{array}{l}\text { Rainfall only, SSP } 5.5 \mathrm{mg} \\
\text { TP ha-1, DAP } 9.0 \mathrm{mg} \mathrm{TP} \\
\text { ha }^{-1}\end{array}$ & Nash et al., 2004 \\
\hline New Zealand & $\begin{array}{l}\text { SSP, PastureZeal, } \\
\text { serpentine super, Gafsa } \\
\text { reactive phosphate } \\
\text { applied at } 30 \mathrm{~kg} \mathrm{P} \mathrm{ha}^{-1} \\
\text { (water soluble P in each } \\
\text { fertilizer, } 82.8,56.7,12 \text {, } \\
\text { and } 0.9 \mathrm{~g} \mathrm{~kg}^{-1} \text { ) }\end{array}$ & 0.000021 & $\begin{array}{l}\text { Simulated rainfall ( } 17 \mathrm{~mm} \\
\mathrm{~h}^{-1} \text { with samples taken } \\
\text { for } 1 \mathrm{~h} \text { after flow started) } \\
\text { on intact turfs measuring } \\
\text { overland flow }\end{array}$ & $\begin{array}{l}\sim 0.01 \text { to } \sim 70 \mathrm{mg} \mathrm{DRP} \mathrm{L}^{-1} \\
\sim 0.05 \text { to } \sim 78 \mathrm{mg} \mathrm{TP} \mathrm{L}^{-1}\end{array}$ & - & $\begin{array}{c}\text { McDowell and Catto, } \\
2005\end{array}$ \\
\hline USA & $\begin{array}{c}\text { North Carolina PR, low- } \\
\text { grade SSP, TSP (water } \\
\text { soluble P contents 0.6, } \\
39.9 \text {, and } 159 \mathrm{~g} \mathrm{~kg}^{-1} \text { ) } \\
\text { applied at a rate of } \\
100 \mathrm{~kg} \mathrm{TP} \mathrm{ha}^{-1}\end{array}$ & 0.0002 & $\begin{array}{l}\text { Simulated rainfall (50 } \\
\mathrm{mm} \mathrm{h}^{-1} \text { for } 30 \text { min after } \\
\text { runoff commenced) } \\
\text { applied to field plots with } \\
\text { orchardgrass and } \\
\text { no-till corn }\end{array}$ & $\begin{array}{l}\text { Orchardgrass and no-till } \\
\text { corn treatments } \\
0.27-90.47 \mathrm{mg} \mathrm{DRP} \mathrm{L}^{-1} \\
0.34-98.06 \mathrm{mg} \mathrm{TP} \mathrm{L}^{-1}\end{array}$ & $\begin{array}{l}\text { Orchardgrass only } \\
0.23-32.16 \mathrm{~kg} \text { DRP ha } \\
0.31-33.16 \mathrm{~kg} \mathrm{TP} \mathrm{ha}^{-1}\end{array}$ & $\begin{array}{l}\text { Shigaki et al., } \\
2006\end{array}$ \\
\hline USA & $\begin{array}{l}\text { TSP applied at a rate of } \\
39 \mathrm{~kg} \mathrm{TP} \mathrm{ha}^{-1}\end{array}$ & 0.00015 & $\begin{array}{l}\text { Simulated rainfall (50 } \\
\mathrm{mm} \mathrm{h}^{-1} \text { for } 30 \text { min after } \\
\text { runoff commenced) } \\
\text { applied to field plots with } \\
\text { Bermudagrass pasture }\end{array}$ & $<23 \mathrm{mg} \mathrm{DRP} \mathrm{L}^{-1}$ & $\begin{array}{l}<3.22 \mathrm{~kg} \mathrm{DRP} \mathrm{ha}^{-1} \\
<3.86 \mathrm{~kg} \mathrm{TP} \mathrm{ha}^{-1}\end{array}$ & Franklin et al., 2006 \\
\hline USA & $\begin{array}{c}\text { Mono-ammonium } \\
\text { phosphate either } \\
\text { incorporated or surface } \\
\text { applied or sliced surface } \\
\text { applied at a rate of } \\
76 \mathrm{~kg} \mathrm{P} \mathrm{ha}^{-1} \text { ) }\end{array}$ & 0.0004 & $\begin{array}{l}\text { Simulated rainfall (50 } \\
\mathrm{mm} \mathrm{h}^{-1} \text { for } 20 \text { min after } \\
\text { runoff commenced) } \\
\text { applied to field plots with } \\
\text { Bermudagrass and mixed } \\
\text { grass forage }\end{array}$ & $\begin{array}{l}<1 \text { to } 17 \mathrm{mg} \mathrm{DRP} \mathrm{L}^{-1} \\
0.56-21.91 \mathrm{mg} \mathrm{TP} \mathrm{L}^{-1}\end{array}$ & $\begin{array}{c}\text { Over } 2 \text { simulations } \\
0.058-1.45 \mathrm{~kg} \mathrm{DRP} \mathrm{ha}^{-1} \\
0.104-1.74 \mathrm{mg} \mathrm{TP} \mathrm{ha}^{-1}\end{array}$ & Pote et al., 2006 \\
\hline USA & $\begin{array}{l}\text { North Carolina PR, low- } \\
\text { grade SSP, TSP (water } \\
\text { soluble P contents 0.6, } \\
39.9 \text { and } 159 \mathrm{~g} \mathrm{~kg}^{-1} \text { ) } \\
\text { applied at a rate of } \\
100 \mathrm{~kg} \mathrm{TP} \mathrm{ha}^{-1}\end{array}$ & 0.00002 & $\begin{array}{l}\text { Simulated rainfall ( } 25,50, \\
\text { and } 75 \mathrm{~mm} \mathrm{~h}^{-1} \text { to achieve } \\
25 \mathrm{~mm} \text { application volume) } \\
\text { applied to trays planted } \\
\text { with ryegrass }\end{array}$ & $\begin{array}{l}0.10-32.07 \mathrm{mg} \mathrm{DRP} \mathrm{L}^{-1} \\
0.16-34.39 \mathrm{mg} \mathrm{TP} \mathrm{L}^{-1}\end{array}$ & - & Shigaki et al., 2007 \\
\hline Australia & $\begin{array}{l}\text { A mixture of single and } \\
\text { TSP was applied at rates } \\
\text { of } 0,20,40,80 \mathrm{~kg} \mathrm{P} \mathrm{ha}^{-1}\end{array}$ & 0.125 & $\begin{array}{c}\text { Natural rainfall and } \\
\text { sprinkler irrigation ( } 8 \\
\mathrm{~mm} \mathrm{~h}^{-1} \text { for } 10 \mathrm{~h} \text { ) induced } \\
\text { overland flow from } \\
\text { ryegrass and white clover } \\
\text { grazed pasture }\end{array}$ & $\begin{array}{l}\text { DRP is } 86 \% \text { of TP } \\
0.86-11.13 \mathrm{mg} \mathrm{TP} \mathrm{L}^{-1}\end{array}$ & $\begin{array}{c}0.16-1.11 \mathrm{~kg} \mathrm{TP} \mathrm{ha}^{-1} \\
\text { annually }\end{array}$ & $\begin{array}{l}\text { Dougherty et al., } \\
2008\end{array}$ \\
\hline New Zealand & $\begin{array}{l}\text { Superphosphate or } \\
\text { reactive PR applied at } \\
20-25 \mathrm{~kg} \mathrm{P} \mathrm{ha}^{-1}\end{array}$ & 12 & $\begin{array}{l}\text { Natural rainfall on hill } \\
\text { country pasture measuring } \\
\text { streamflow }\end{array}$ & $\begin{array}{l}0.01-2.00 \mathrm{mg} \mathrm{DRP} \mathrm{L}^{-1} \\
0.01-12.0 \mathrm{mg} \mathrm{TP} \mathrm{L}^{-1}\end{array}$ & 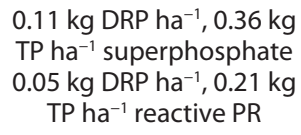 & $\begin{array}{l}\text { McDowell et al., } \\
2010\end{array}$ \\
\hline
\end{tabular}

† DAP, di-ammonium phosphate; PR, phosphate rock; SSP, single superphosphate; TP, total P; TSP, triple superphosphate.

\# DRP, dissolved reactive $P$; $P R$, phosphate rock; TDP, total dissolved $P$; TP, total $P$; TPP, total particulate $P$.

increased from 17 to $57 \mathrm{mg} \mathrm{P} \mathrm{kg}^{-1}$ during the study, there appeared to be no relationship between soil test $\mathrm{P}$ and the base (i.e., background) P concentrations (Fig. 5d). The results of the Darnum and Macalister Research Farm studies are consistent with similar field-scale studies elsewhere (Owens and Shipitalo, 2006).

The additive models developed for Darnum and the Macalister Research Farm have been used, along with fertilizer distribution, grazing and regional overland flow data, to quantitatively estimate $\mathrm{P}$ exports attributable to recently applied fertilizer (Nash and Hannah, 2011). The resulting MonteCarlo simulations and Bayesian Networks demonstrate that for systems like those for which the equations were derived, $\mathrm{P}$ exports directly attributable to fertilizer application (i.e., shortterm effects of recently applied fertilizer) are unlikely to have a major impact (i.e., $<10 \%$ ) on annual P exports. Fertilizer application accounted for between 5 and $18 \%$ and between 4 and $17 \%$ of total P exports annually from Darnum and the Macalister Research Farm, respectively. In this study, it was assumed that fertilizer application and overland flow occurred at random within a given month. In many regions, conditions conducive to overland flow, such as high antecedent soil moisture, preclude fertilizer application. Moreover, as a result of extension activities, farmers are now less inclined to apply 

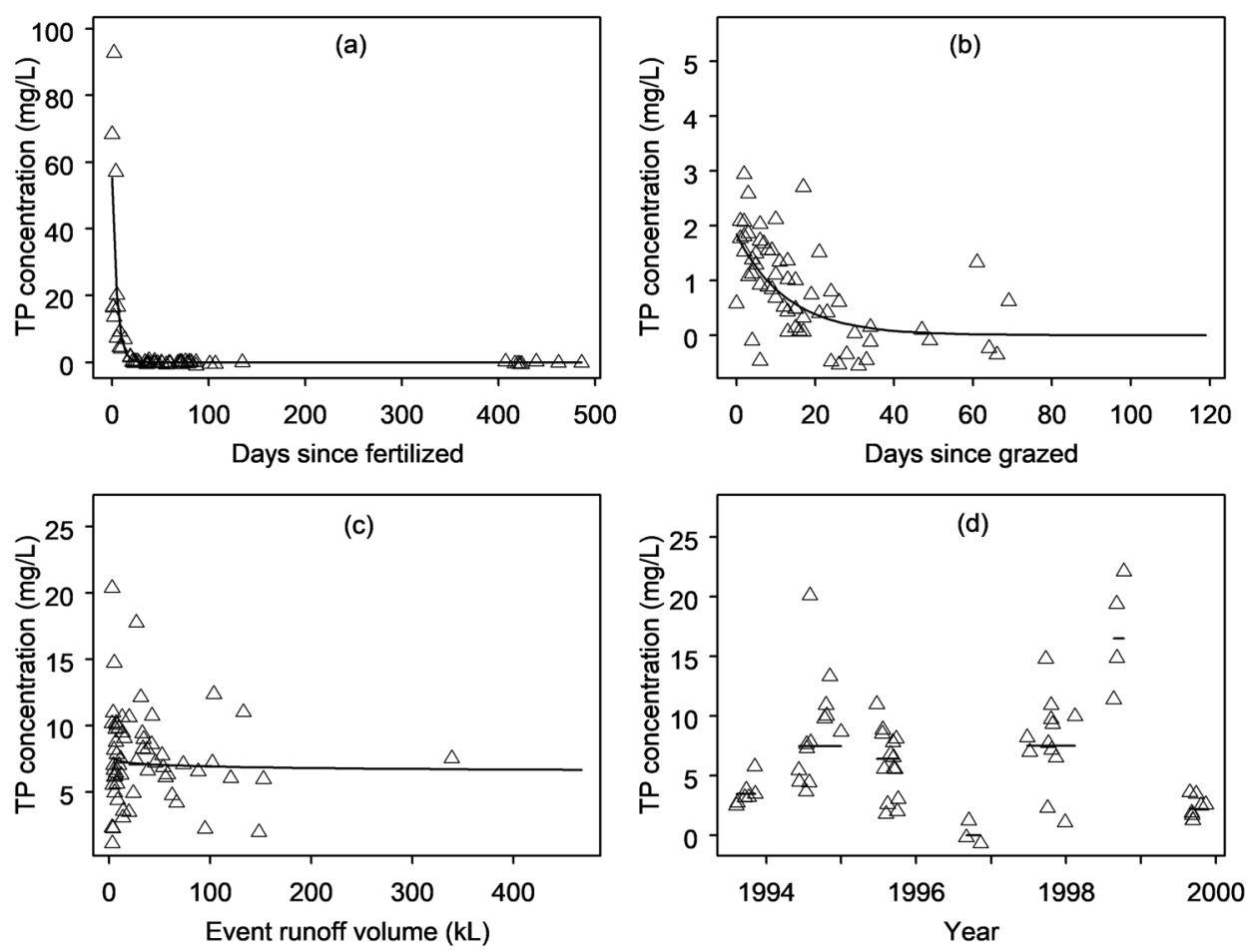

Fig. 5. Relationships between adjusted (partial residual) total P concentrations (TP) in overland flow and (a) days since fertilizer was applied, (b) days since last grazed, (c) overland flow volume for the event, and (d) the effect of year, for a site at Darnum in southeastern Australia. Points are back-transformed partial residuals (i.e., data with other model term estimates subtracted out). Lines are the relevant terms from the fitted model. Source: Nash et al. (2005).

fertilizer immediately before overland flow, inducing irrigation or rainfall (Department of Primary Industries, 2006). It follows that improved management of fertilizer application on a regional basis would of itself probably result in only a small (i.e., $<10 \%$ ) decline in total $P$ exports.

Interestingly, in the Bayesian Networks discussed above, grazing appeared to make a bigger contribution to total P exports than fertilizer. While such findings need to be viewed with caution, they are plausible. Grazing increases water-available P in the mixing layer at the soil surface (McDowell et al., 2007; Mundy et al., 2003; Nexhip et al., 1997), and grazing occurs more often at times of the year when overland flow is more frequent (e.g., during the irrigation season and late winter and early spring in rainfed systems).

A New Zealand study (McDowell and Catto, 2005) used simulated rainfall on intact soil turfs $(1050 \mathrm{~mm}$ long by $200 \mathrm{~mm}$ wide) to investigate the effects of different fertilizer formulations on P exports in overland flow 1, 7, 14, 28, 112, and $192 \mathrm{~d}$ after fertilizer application. Decay curves were used in conjunction with monthly overland flow data to show that the risk of direct fertilizer P exports was greatest in June when most overland flow occurs. The decay curves were then used with 2 yr of field monitoring data to simulate $\mathrm{P}$ exports from fertilizer applications occurring on 1 June and 1 December. From this semi-empirical approach, it was concluded that if applied in December, soluble $P$ fertilizers would account for $<10 \%$ of total $P$ exports for the year (McDowell et al., 2009b; McDowell and Catto, 2005). While the methodology did not readily lend itself to detailed scenario testing and the outcomes of the study have been questioned (Quin et al., 2004), they are consistent with other modeling (Vadas et al., 2015).

\section{Implications for Fertilizer Good Management Practices}

Under good management practice where the principles of 4Rs are followed (Bruulsema, 2018; Johnston and Bruulsema, 2014), P exports attributable to recently applied fertilizer can be a relatively small proportion (i.e., $<10 \%$ ) of total $\mathrm{P}$ exports. However, particularly in New Zealand, where intensive pastoral agriculture has expanded into areas of increased risk for $\mathrm{P}$ exports (i.e., greater slope, poorer soil P sorption), the adverse consequences of inappropriate selection of the form, placement, rate, and timing of $\mathrm{P}$ fertilizer applications are increasing. For example, fertilizer selection is important in situations where there is regular and frequent rainfall (McDowell, 2010), poor soil P sorption (McDowell and Monaghan, 2015), high hydraulic fluxes (Simmonds et al., 2015), or soil properties (e.g., acid soil $\mathrm{pH}$ ) that result in the rapid dissolution of calcium phosphates (Simmonds et al., 2016).

Due to the variability in farming systems, we use three model systems with varying hydrology to demonstrate the principles for selecting fertilizers to minimize P exports soon after their application (Fig. 6). Such systems are common to Australia and New Zealand, and while recognizing there are other options (Lombi et al., 2004; Lombi et al., 2005; Smith et al., 2016), discussion here is limited to the surface application of the mineral fertilizer compounds commonly used in pastoral systems.

\section{Model System 1: Overland Flow-Dominated Hydrology}

In overland flow-dominated systems (Fig. 6a) with seasonal rainfall, basal (i.e., annual) applications of $\mathrm{P}$ fertilizers should be undertaken when the probability of overland flow 
b

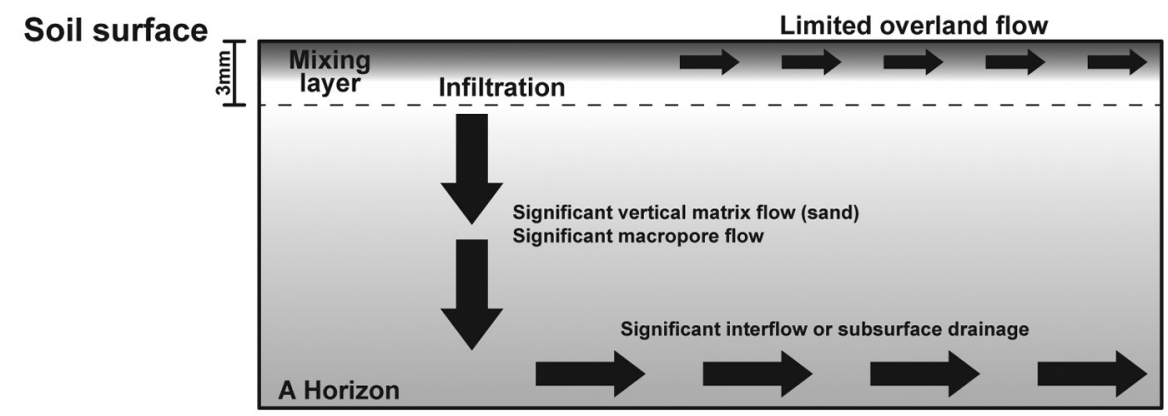

C

Soil surface

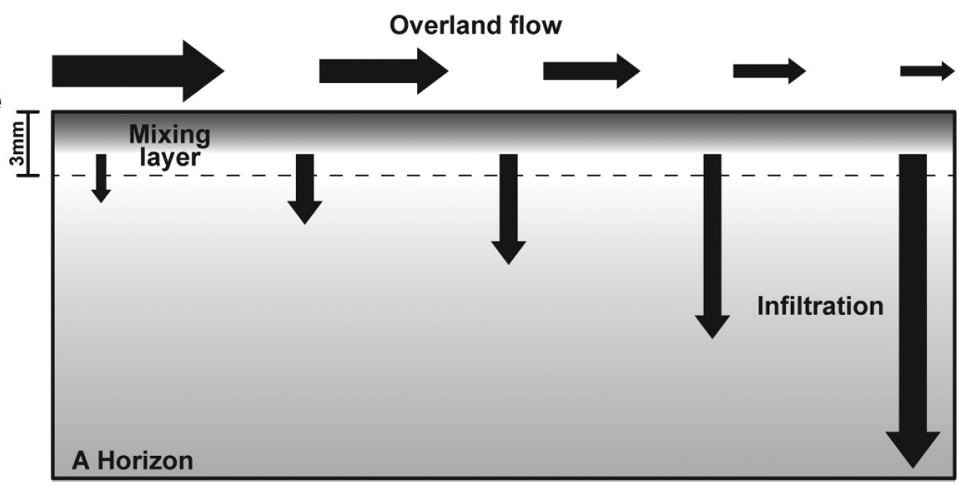

Fig. 6. Schematic representation of field-scale hydrology in selected farming systems: (a) overland flow dominant hydrology, (b) infiltration dominant hydrology including macropore flow to subsurface drains, and (c) border-check irrigation hydrology.

is lowest, for example, late autumn in southeastern Australia. Late autumn and early winter rainfall onto dry soil would be expected to transport dissolved P below the soil surface, lowering $\mathrm{P}$ concentrations in the mixing layer. Moreover, by maximizing the time between fertilizer application and overland flow, retention reactions should also minimize the P exports. Under those circumstances, fertilizer selection should be based on agronomic efficiency.

Fertilizer selection is likely to be more important where there is frequent (e.g., $>50$ overland flow events) and reliable (e.g., $>4000 \mathrm{~mm}$ rainfall annually) year-round rainfall (McDowell, 2010), the soils are hydrophobic (Simmonds et al., 2017), or there are accidental additions of fertilizer-P to stream channels from aerial applications in steeper country $(\mathrm{McD}$ owell et al., 2010). In those instances, sparingly soluble or slow release fertilizer could well be the most appropriate, providing the agronomic objectives for its application are achieved. In a paired-catchment study (McDowell et al., 2010), application of reactive rock phosphate over $3 \mathrm{yr}$ decreased DRP and TP loads in streamflow by 58 and 30\%, respectively, compared with the same rate of $\mathrm{P}$ applied as superphosphate. However, there are many site-specific factors to consider.

In New Zealand, for example, the application of reactive $P R$ has been shown to produce the same mass of pasture as TSP after $3 \mathrm{yr}$, provided there is sufficient rainfall $(>800 \mathrm{~mm})$ and the soil $\mathrm{pH}$ is $<6$ to allow the PR to dissolve (Sinclair et al., 1990). The lag in the performance of PR means that it cannot be used as a capital application of $\mathrm{P}$ to raise soil fertility quickly and must also be slowly introduced, increasing the proportion in the blend by a third each year.

While partially water-soluble fertilizers are probably the most appropriate form of $\mathrm{P}$ for applications in periods when overland flow is likely, that may not always be the case. For example, in southeastern Australia, formulations containing $\mathrm{P}$ (sometimes referred to as booster products) are used to stimulate shortterm pasture production in early spring. If applications can be timed to avoid overland flow in the next $7 \mathrm{~d}$ or more (McDowell and Catto, 2005; Nash et al., 2004), P exports from water-soluble $P$ in booster products should be relatively minor. In that case, the required rootzone $\mathrm{P}$ concentration could be achieved at a lower total $\mathrm{P}$ application rate than if partially water-soluble forms of $\mathrm{P}$ had been used. It follows that when managed appropriately and consistently, watersoluble P in booster products can help minimize the legacy effects (i.e., background exports) associated with increasing residual $\mathrm{P}$ in the soil-plant system. This is particularly true for very intensive systems where cattle traffic may enhance particulate P exports, which might include fertilizer solids, during vulnerable times of the year.

\section{Model System 2: Subsurface Flow-Dominated Hydrology}

In subsurface flow-dominated systems (Fig. 6b), the potential for $\mathrm{P}$ exports depends the ability of the soil to remove $\mathrm{P}$ in transit. Where macropore flow dominates, surface applications of $\mathrm{P}$ can result in significant $\mathrm{P}$ exports if drainage occurs soon after application. This is especially true where artificial drainage systems intercept vertical macropore flow and convey it to waterways (Monaghan et al., 2016). Erosion of macropores and drains from frequent flows can exacerbate $P$ exports from these systems (Addiscott and Thomas, 2000).

As in systems where overland flow dominates, the timing of fertilizer application in relation to drainage is important in determining the most appropriate fertilizer formulation. Fertilizer 
formulation is of lesser but not negligible importance where application and macropore drainage are unlikely to coincide. Less-soluble fertilizers may well be appropriate where they are applied to wet or dry cracked soils (Williams et al., 2003, 2016). Fertilizer $\mathrm{P}$ could be applied during pasture renewal where cultivation destroys macropores in the topsoil. However, the longterm effectiveness of this strategy is questionable given that macropore flow is often restored by earthworm activity within a year of cultivation (Dodd et al., 2014), pasture renovation is not usually an annual event, and cultivation may simultaneously increase erosion and particulate $\mathrm{P}$ exports in overland flow (Williams et al., 2016).

In systems where matrix flow predominates, $\mathrm{P}$ exports are largely determined by the P sorption capacity of the soil. For example, in New Zealand, subsurface drainage from runoff plots with varying anion storage capacity (ASC) (i.e., P sorption potential) were compared (McDowell and Monaghan, 2015). Over an 18-mo period, drainage from the plots was similar across all three sites (521-574 mm). Exports from a Podzol (55\% anion storage capacity) that had been developed into pasture for $10 \mathrm{yr}$ was $1.7 \mathrm{~kg}$ TDP ha ${ }^{-1}$. However, the export of TDP leached to $35-\mathrm{cm}$ depth from an organic soil was $87 \mathrm{~kg} \mathrm{P} \mathrm{ha}^{-1}$ ( 89\% of fertilizer-P added).

Mitigation measures tested in a New Zealand study included reduced $\mathrm{P}$ applications, applying alum $\left(50 \mathrm{~kg} \mathrm{Al} \mathrm{ha}^{-1}\right)$ to improve the $\mathrm{P}$ sorption and applying low water-soluble reactive $\mathrm{PR}$ (McDowell, 2015). Alum reduced exports by approximately onethird, but that effect was likely to be transient as alum would be quickly leached from the soil or converted into more crystalline and unreactive forms. The application of PR was marginally effective but did not lessen P exports when $\mathrm{pH}$ was $<5.5$ (Simmonds et al., 2016). Hence, it was concluded that $P$ application rates should be decreased and the intensity of the system lowered.

In Western Australian, studies using sandy pasture soils, $\mathrm{P}$ in leachate from SSP and coastal superphosphate (equal parts SSP, PR, and sulfur) were compared. Phosphorus was released quicker from SSP than coastal superphosphate and increased P exports by 10 to $40 \%$. However, in the long-term, non-watersoluble components of fertilizer contributed to $\mathrm{P}$ in leachate, emphasizing the need to consider the legacy effects of fertilizer P (Weaver et al., 1988a, 1988b).

Subsurface pathways can also dominate the hydrology of irrigated pasture systems. Under spray irrigation, the potential for overland flow should be minimal, but substantial P exports can occur via subsurface flow, especially if the soil has a poor capacity to adsorb $\mathrm{P}$ or irrigation practice is poor. In a study in Central Otago, New Zealand, P exported in subsurface drainage was measured for $3 \mathrm{yr}$ under a uniform rate irrigation from a sandy-textured soil (anion storage capacity <20\%) (McDowell, 2017). Exports decreased by $70 \%$ following soil mapping and the recalibration of water application rates to match soil types beneath the irrigator. This example clearly shows the benefits of considering hydrology in combination with the 4 Rs of nutrient stewardship, and the site-specific nature of $\mathrm{P}$ exports through subsurface pathways. While a wide range of factors bears consideration in selecting an appropriate fertilizer, where agronomically viable alternatives are available, water-soluble fertilizers are probably inappropriate for many systems with significant subsurface drainage (e.g., macropore flow, poor soil P sorption).

\section{Model System 3: Border-Check Irrigation}

Border-check irrigation, which is used to supplement natural rainfall, has a consistent pattern of hydrology (Fig. 6c). While gradually being changed to spray irrigation, border-check irrigation was once common in both Australia and New Zealand. Border-check irrigation is characterized by high infiltration rates at the wetting front. Here water traverses dry soil but infiltration rates decline rapidly behind the wetting front, back up the bay toward the water inlet. Tailwater (e.g., overland flow) from behind the wetting front enters drains at the foot of the bay, carrying with it predominantly dissolved $\mathrm{P}$.

In border-check irrigation systems, land managers control water inflow and outflows to and from their bays. It follows that the best way of lessening P exports from P fertilizer applied during the irrigation season is short watering (i.e., minimizing drainage by not watering the final portion of the bay) and/or recycling tailwaters. However, some drainage (i.e., tailwater) from bays and farms is inevitable.

It is tempting to think that sparingly soluble or slow release fertilizers will minimize $\mathrm{P}$ exports from border-check irrigation. This is probably true if fertilizers are applied and irrigation occurs a week or two later. However, if high-risk periods are avoided, New Zealand studies have shown that for soils receiving long-term applications of reactive PR, P exports in tailwater $>60$ $\mathrm{d}$ after application can be greater than from soils receiving the same (i.e., long-term) rate of $\mathrm{P}$ applied as SSP. As a result, annual $\mathrm{P}$ exports may be higher from reactive $\mathrm{PR}$ as compared to watersoluble P fertilizer (McDowell et al., 2003).

Water solubility is not the only factor to consider in selecting the most appropriate fertilizer for border-check irrigation systems. An Australian laboratory study examined the mobilization of $\mathrm{P}$ from individual fertilizer granules and showed that when applied to acidic soil, $\mathrm{P}$ was released more rapidly from DAP than SSP (Nash et al., 2003). That result was consistent with subsequent field trials where P concentrations in flow sampled immediately behind the true wetting front were lower for DAP than SSP. It was postulated that compared with SSP, P was rapidly released from DAP and infiltrated at the wetting front during irrigation, lowering the $\mathrm{P}$ concentration in the mixing layer and the quantity of $\mathrm{P}$ subsequently available for mobilization (Nash et al., 2004). In that study, rainfall on recently irrigated pastures yielded the opposite result. That finding was attributed to a lack of infiltration (i.e., mass flow of $P$ below the mixing layer) and the $\mathrm{P}$ from DAP being released more quickly into the mixing layer and mobilized in the wetting front. A more rapid release of $\mathrm{P}$ from ammoniated phosphates than SSP has been observed in other studies (Degryse et al., 2013). Especially in alkaline soils with high exchangeable calcium, SSP dissolution is delayed and diffusion from the granule initially limited by a common ion effect. Such studies suggest that there will be soilspecific differences in the relative benefits of compounds within solubility classes (i.e., SSP and DAP).

\section{Concluding Comments}

There is little doubt that not following the $4 \mathrm{R}$ principles for $P$ fertilizers can result in excessive $\mathrm{P}$ exports from grazing systems in Australasia. This paper has focused on the short-term effects of fertilizer application on P exports and the selection of 
appropriate compounds and formulations to minimize the associated risk to downstream water resources. Numerous studies have shown what is possible soon after fertilizers are applied. But the important question is not "What is possible?" but "What is probable?"

Using conceptually sound empirical models, it is possible to investigate the likely contribution of recently applied fertilizer to overall $\mathrm{P}$ exports from these systems. These analyses suggest that with good management practice, recently applied fertilizers make a minor (e.g., <10\%) contribution to total P exports. But that is not necessarily the case where, for example, the soil has a poor sorption capacity, there is frequent rainfall, or fertilizer applications coincide with drainage events. However, by understanding the processes responsible for $\mathrm{P}$ mobilization, and the pathways through which $\mathrm{P}$ may be exported, it should be possible to mitigate the short-term risks associated with fertilizer use through prudent selection of compounds and formulations, and optimizing their application in terms of rate, timing and placement (i.e., applying the $4 \mathrm{R}$ concept).

Fertilizer good management practices are cost effective compared with other mitigation strategies that occur at the edge of the field or in-stream (McDowell and Nash, 2012). Their catchment-scale efficacy and cost-effectiveness in mitigating P exports is improved if they are targeted at critical source areas (i.e., areas within a farm or farms within a catchment) where surface and/or subsurface drainage are prevalent. For example, when appropriate $\mathrm{P}$ mitigation strategies were applied to 14 catchments in New Zealand, $\mathrm{P}$ exports were estimated to be halved with minimal impact on farm profitability ( $<2 \%$ of farm earnings before interest and tax) (McDowell, 2014). In New Zealand, semiquantitative evidence suggests that despite intensive land use expanding, good management practice combined with increasing awareness of $\mathrm{P}$ and critical source areas, and their reinforcement through voluntary processes and regulation, has seen stream water P concentrations decrease in the last 10 years (McDowell et al., 2019).

\section{Conflict of Interest}

The authors declare no conflict of interest.

\section{Acknowledgments}

Funding for this review was provided by the Fertiliser Association of New Zealand.

\section{References}

Addiscott, T.M., and D. Thomas. 2000. Tillage, mineralization, and leaching: Phosphate. Soil Tillage Res. 53:255-273. doi:10.1016/ S0167-1987(99)00110-5

Ahuja, L.R. 1990. Modeling soluble chemical transfer to runoff with rainfall impact as a diffusion process. Soil Sci. Soc. Am. J. 54:312-321. doi:10.2136/ sssaj1990.03615995005400020003x

Ahuja, L.R., and O.R. Lehman. 1983. The extent and nature of rainfall-soil interaction in the release of soluble chemicals to runoff. J. Environ. Qual. 12:34-40. doi:10.2134/jeq1983.00472425001200010005x

Ahuja, L.R., A.N. Sharpley, M. Yamamoto, and R.G. Menzel. 1981. The depth of rainfall-runoff-soil interaction as determined by ${ }^{32} \mathrm{P}$. Water Resour. Res. 17:969-974. doi:10.1029/WR017i004p00969

Amerman, C.R. 1965. The use of unit-source watershed data for runoff prediction. Water Resour. Res. 1:499-507. doi:10.1029/WR001i004p00499

ANZECC and ARMCANZ. 2000. Australian and New Zealand guidelines for fresh and marine water quality. Australian Water Association, Artarmon, NSW.

ANZECC and ARMCANZ. 2018. Australian and New Zealand guidelines for fresh and marine water quality. Department of Agriculture and Water resources, Australian Government, Canberra, ACT.
Austin, N.R., J.B. Prendergast, and M.D. Collins. 1996. Phosphorus losses in irrigation runoff from fertilized pasture. J. Environ. Qual. 25:63-68. doi:10.2134/jeq1996.00472425002500010008x

Ballantine, D.J., and R.J. Davies-Colley. 2014. Water quality trends in New Zealand rivers: 1989-2009. Environ. Monit. Assess. 186:1939-1950. doi:10.1007/s10661-013-3508-5

Barlow, K. 2003. Paddock to farm scaling of phosphorus export from irrigated agriculture: Farm drains as a source or sink of phosphorus. Ph.D. diss., University of Melbourne, Melbourne, Australia.

Barrow, N.J. 1983. On the reversibility of phosphate sorption by soils. J. Soil Sci. 34:751-758. doi:10.1111/j.1365-2389.1983.tb01069.x

Barrow, N.J. 1989. The reaction of plant nutrients and pollutants with soil. Aust. J. Soil Res. 27:475-492. doi:10.1071/SR9890475

Beckett, R., and B.T. Hart. 1993. Use of field flow fractionation techniques to characterise aquatic particles, colloids, and macromolecules. In: J. Buffle and H.P. van Leeuwen, editors, Environmental particles. Lewis, Boca Raton, FL.

Bell, L.C., and C.A. Black. 1970a. Crystalline phosphates produced by interaction of orthophosphate fertilisers with slightly acid and alkaline soils. Soil Sci. Soc. Am. Proc. 34:735-740. doi:10.2136/ sssaj1970.03615995003400050020x

Bell, L.C., and C.A. Black. 1970b. Transformations of dibasic calcium phosphate dihydrate and octocalcium phosphate in slightly acid and alkaline soils. Soil Sci. Soc. Am. Proc. 34:583-587. doi:10.2136/ sssaj1970.03615995003400040014x

Birch, P. 1982. Phosphorus export from coastal plain drainage into the Peel-Harvey estuarine system of Western Australia. Mar. Freshwater Res. 33:23-32. doi:10.1071/MF9820023

Bolan, N.S., and M.J. Hedley. 1997. Developments in some aspects of reactive phosphate rock research and use in New Zealand. Aust. J. Exp. Agric. 37:861-884. doi:10.1071/EA96104

Bouldin, D.R., J.R. Lehr, and E.C. Sample. 1960. The effect of associated salts on transformations of monocalcium phosphate monohydrate at the site of application. Soil Sci. Soc. Am. Proc. 24:464-468. doi:10.2136/ sssaj1960.03615995002400060015x

Broberg, O., and K. Pettersson. 1988. Analytical determination of orthophosphate in water. Hydrobiologia 170:45-59. doi:10.1007/BF00024898

Brogan, J., M. Crowe, and G. Carty. 2001. Developing a national phosphorus balance for agriculture in Ireland. Environment Protection Agency, Ireland, Johnstown Castle Estate, County Wexford.

Bromfield, S.M., and O.L. Jones. 1972. The initial leaching of hayed-off pasture plants in relation to the recycling of phosphorus. Aust. J. Agric. Res. 23:811-824. doi:10.1071/AR9720811

Bruulsema, T. 2018. Managing nutrients to mitigate soil pollution. Environ. Pollut. 243:1602-1605. doi:10.1016/j.envpol.2018.09.132

Burton, J.D. 1973. Problems in the analysis of phosphorus compounds. Water Res. 7:291-307. doi:10.1016/0043-1354(73)90170-X

Bush, B.J., and N.R. Austin. 2001. Timing of phosphorus fertilizer application within an irrigation cycle for perennial pasture. J. Environ. Qual. 30:939946. doi:10.2134/jeq2001.303939x

Canadian Council of Ministers of the Environment (CCME). 2004. Canadian water quality guidelines for protection of aquatic life: Phosphorus- Canadian guidance framework for the management of freshwater systems. In: Canadian environmental quality guidelines, 2004. Canadian Council of Ministers of the Environment, Winnipeg, MB, Canada.

Chien, S.H., and R.G. Menon. 1995a. Agronomic evaluation of modified phosphate rock products. Fert. Res. 41:197-209. doi:10.1007/BF00748309

Chien, S.H., and R.G. Menon. 1995b. Factors affecting the agronomic effectiveness of phosphate rock for direct application. Fert. Res. 41:227-234. doi:10.1007/BF00748312

Chien, S.H., L.I. Prochnow, and H. Cantarella. 2009. Recent developments of fertilizer production and use to improve nutrient efficiency and minimize environmental impacts. Adv. Agron. 102:267-322. doi:10.1016/ S0065-2113(09)01008-6

Chien, S.H., L.I. Prochnow, S. Tu, and C.S. Snyder. 2011. Agronomic and environmental aspects of phosphate fertilizers varying in source and solubility: An update review. Nutr. Cycling Agroecosyst. 89:229-255. doi:10.1007/ s10705-010-9390-4

Chien, S.H., P.W.G. Sale, and L.L. Hammond. 1989. Comparison of the effectiveness of phosphorus fertiliser products: Phosphorus requirements for sustainable agriculture in Asia and Oceania. International Rice Research Institute, Manila, Philippines. p. 143-156.

Chittleborough, D.J. 1992. Formation and pedology of duplex soils. Aust. J. Exp. Agric. 32:815-825. doi:10.1071/EA9920815

Cooke, G.D., E.B. Welch, S.A. Peterson, and P.R. Newroth. 1993. Restoration and management of lakes and reservoirs. 2nd ed. Lewis, Boca Raton, FL. 
Cox, J.W., D.J. Chittleborough, H.J. Brown, A. Pitman, and J.C.R. Varcoe. 2002. Seasonal changes in hydrochemistry along a topsequence of texture-contrast soils. Aust. J. Soil Res. 40:581-604. doi:10.1071/SR01042

Cox, J.W., C.A. Kirkby, D.J. Chittleborough, N.K. Fleming, and L.J. Smythe. 2000. Mobility of phosphorus through intact soil cores collected from the Adelaide Hills, South Australia. Aust. J. Soil Res. 38:973-990. doi:10.1071/SR99125

Cox, J.W., and D.J. McFarlane. 1995. The causes of waterlogging in shallow soils and their drainage in south western Australia. J. Hydrol. 167:175-194. doi:10.1016/0022-1694(94)02614-H

Cresswell, H.P., D.E. Smiles, and J. Williams. 1992. Soil structure, soil hydraulic properties and the soil water balance. Aust. J. Soil Res. 30:265-283. doi:10.1071/SR9920265

da Cruz, D.F., R. Bortoletto-Santos, G.G.F. Guimarães, W.L. Polito, and C. Ribeiro. 2017. Role of polymeric coating on the phosphate availability as a fertilizer: Insight from phosphate release by castor polyurethane coatings. J. Agric. Food Chem. 65:5890-5895. doi:10.1021/acs.jafc.7b01686

Dairy Australia. 2018. Best management practices. Fert\$mart. http:// fertsmart.dairyingfortomorrow.com.au/getting-it-right/ best-management-practices/.

Dairy Australia. 2019. Our regions. Dairy Australia, Melbourne, VIC, Australia. Davies, D.B., and D. Payne. 1988. Management of soil physical properties. In: A. Wild, editor, Russell's soil conditions and plant growth. John Wiley \& Sons, New York. p. 412-448.

Degryse, F., B. Ajiboye, R.D. Armstrong, and M.J. McLaughlin. 2013. Sequestration of phosphorus-binding cations by complexing compounds is not a viable mechanism to increase phosphorus efficiency. Soil Sci. Soc. Am. J. 77:2050-2059. doi:10.2136/sssaj2013.05.0165

Degryse, F., and M.J. McLaughlin. 2014. Phosphorus diffusion from fertilizer: Visualization, chemical measurements, and modeling. Soil Sci. Soc. Am. J. 78:832-842. doi:10.2136/sssaj2013.07.0293

Department of Primary Industries. 2006. Gippsland nutrient extension program evaluation. State of Victoria, Department of Primary Industries, Melbourne, Australia.

Dillaha, T.A., J.H. Sherrard, D. Lee, S. Mostaghimi, and V.O. Shanholtz. 1988. Evaluation of vegetative filter strips as a best management practice for feed lots. J. Water Pollut. Control Fed. 60:1231-1238.

Dodd, R.J., R.W. McDowell, and L.M. Condron. 2014. Is tillage an effective method to decrease phosphorus loss from phosphorus enriched pastoral soils? Soil Tillage Res. 135:1-8. doi:10.1016/j.still.2013.08.015

Dodds, W.K., and V.H. Smith. 2016. Nitrogen, phosphorus, and eutrophication in streams. Inland Waters 6:155-164. doi:10.5268/IW-6.2.909

Doody, D., R. Moles, H. Tunney, I. Kurz, D. Bourke, K. Daly, et al. 2006. Impact of flow path length and flow rate on phosphorus loss in simulated overland flow from a humic Gleysol grassland soil. Sci. Total Environ. 372:247-255. doi:10.1016/j.scitotenv.2006.08.029

Dougherty, W.J., P.J. Nicholls, P.J. Milham, E.J. Havilah, and R.A. Lawrie. 2008. Phosphorus fertilizer and grazing management effects on phosphorus in runoff from dairy pastures. J. Environ. Qual. 37:417-428. doi:10.2134/ jeq2007.0049

Drewry, J.J. 2006. Natural recovery of soil physical properties from treading damage of pastoral soils in New Zealand and Australia: A review. Agric. Ecosyst. Environ. 114:159-169. doi:10.1016/j.agee.2005.11.028

Drewry, J.J., K.C. Cameron, and G.D. Buchan. 2008. Pasture yield and soil physical property responses to soil compaction from treading and grazing: A review. Soil Res. 46:237-256. doi:10.1071/SR07125

Edmeades, D.C. 2000. The agronomic effectiveness of lime-reverted and dicalcic superphosphates: A review. N. Z. J. Agric. Res. 43:1-6. doi:10.1080/002 88233.2000 .9513402

Emmett, W.W. 1978. Overland flow. In: M.J. Kirkby, editor, Hillslope hydrology. John Wiley \& Sons, Chichester, UK. p. 145-177.

Engelstad, O.P., and D.T. Hellums. 1992. Water solubility aspects of phosphate fertilisers: Agronomic aspects-A literature review. International Fertiliser Development Center, Muscle Shoals, AL.

Engelstad, O.P., and G.L. Terman. 1980. Agronomic effectiveness of phosphate fertilisers. In: F.E. Khasawneh, E.C. Sample, and J. Kamparth, editors, The role of phosphorus in agriculture. ASA, Madison, WI. p. 311-332.

EPA. 1995. State environment protection policy (waters of Victoria) schedule F5: The Latrobe and Thompson River basins and Merriman Creek catchment. Victorian Environment Protection Authority, Melbourne, VIC, Australia.

EPA. 2003. Nutrient objectives for rivers and streams- ecosystem protection. Environment Protection Authority, Victorian State Government, Melbourne, VIC, Australia.

European Environment Agency. 1998. Europe's environment: The second assessment. European Environment Agency, Copenhagen.
Fertiliser Technology Research Centre, (FTRC). 2019. Technical bulletin: Main characteristics and agronomic performance of triple superphosphate. Fertiliser Technology Research Centre, School of Agriculture Food and Wine, University of Adelaide, Adelaide, SA, Australia. p. 4.

Franklin, D.H., M.L. Cabrera, and V.H. Calvert. 2006. Fertilizer source and soil aeration effects on runoff volume and quality. Soil Sci. Soc. Am. J. 70:8489. doi:10.2136/sssaj2003.0114

Gächter, R., J.M. Ngatiah, and C. Stamm. 1998. Transport of phosphate from soil to surface waters by preferential flow. Environ. Sci. Technol. 32:18651869. doi: $10.1021 /$ es 9707825

Gaudreau, J.E., D.M. Vietor, R.H. White, T.L. Provin, and C.L. Munster. 2002. Response of turf and quality of water runoff to manure and fertilizer. J. Environ. Qual. 31:1316-1322. doi:10.2134/jeq2002.1316

Gerits, J.J.P., J.L.M.P. De Lima, and T.M.W. Van Den Brock. 1990. Overland flow and erosion. In: M.G. Anderson and T.P. Burt, editors, Process studies in hillslope hydrology. John Wiley \& Sons, Chichester, UK. p. 173-214.

Grayson, R.B., C.J. Gippel, B.L. Finlayson, B.T. Hart, R. Hawken, T.A. McMahon, et al. 1994. Mitigation of sediment and nutrient movement from sources in the Latrobe River catchment into the Gippsland Lakes. Land and Water Resources Research and Development Corporation, Canberra, Australia.

Grayson, R.B., K.S. Tan, and A. Western. 2001. Estimation of sediment and nutrient loads into the Gippsland Lakes. CSIRO and University of Melbourne, Melbourne, Australia.

Green, M.B., and D. Wang. 2008. Watershed flow paths and stream water nitrogen-to-phosphorus ratios under simulated precipitation regimes. Water Resour. Res. 44. doi:10.1029/2007WR006139

Greenhill, N.B., K.I. Peverill, and L.A. Douglas. 1983a. Nutrient concentrations in runoff from pasture in Westernport, Victoria. Aust. J. Soil Res. 21:139145. doi:10.1071/SR9830139

Greenhill, N.B., K.I. Peverill, and L.A. Douglas. 1983b. Nutrient loads in surface runoff from sloping perennial pastures in Victoria, Australia. N. Z. J. Agric. Res. 26:503-506. doi:10.1080/00288233.1983.10427028

Greenhill, N.B., K.I. Peverill, and L.A. Douglas. 1983c. Surface runoff from sloping, fertilised perennial pastures in Victoria, Australia. N. Z. J. Agric. Res. 26:227-231. doi:10.1080/00288233.1983.10427065

Greenwood, K.L. and B.M. McKenzie. 2001. Grazing effects on soil physical properties and the consequences for pastures: A review. Aust. J. Exp. Agric. 41:1231-1250.

Guppy, C.N., N.W. Menzies, F.P.C. Blamey, and P.W. Moody. 2005a. Do decomposing organic matter residues reduce phosphorus sorption in highly weathered soils? Soil Sci. Soc. Am. J. 69:1405-1411. doi:10.2136/ sssaj2004.0266

Guppy, C.N., N.W. Menzies, P.W. Moody, and F.P.C. Blamey. 2005b. Competitive sorption reactions between phosphorus and organic matter in soil: A review. Soil Res. 43:189-202. doi:10.1071/SR04049

Hairsine, P. 1996. Comparing grass filter strips and near natural riparian forests for buffering intense hillslope sediment sources. In: I. Rutherford and M. Walker, editors, Stream management ' 96 . Cooperative Research Centre for Catchment Hydrology, Merrijig, VIC, Australia. p. 203-206.

Hairsine, P.B., and R.B. Grayson. 1993. Further perspectives on buffer strips: Surface transport and deposition processes. Land and Water Resources Research and Development Corporation, Canberra, Australia. p. 45-52.

Halliwell, D., J. Coventry, and D. Nash. 2000a. Inorganic monophosphate determination in overland flow from irrigated grazing systems. Int. J. Environ. Anal. Chem. 76:77-87. doi:10.1080/03067310008034121

Halliwell, D., J. Vanderzalm, R. Lyall, and D.M. Nash. 2000b. Is there a relationship between organic carbon and phosphorus in overland flow from flood irrigation grazing systems. In: National Soils Conference. Australian Society of Soil Science, Inc., Conference, Lincoln University, Christchurch, New Zealand.

Hallows, P.J. 1998. Report on Macalister Irrigation District: Phosphorus reduction options study. Victorian Department of Natural Resources and Environment, Maffra, VIC, Australia.

Hart, M.R., B.F. Quin, and M.L. Nguyen. 2004. Phosphorus runoff from agricultural land and direct fertilizer effects: A review. J. Environ. Qual. 33:19541972. doi: $10.2134 /$ jeq2004.1954

Haygarth, P.M., L.M. Condron, A.L. Heathwaite, B.L. Turner, and G.P. Harris. 2005. The phosphorus transfer continuum: Linking source to impact with an interdisciplinary and multi-scaled approach. Sci. Total Environ. 344:5-14. doi:10.1016/j.scitotenv.2005.02.001

Haygarth, P.M., and S.C. Jarvis. 1997. Soil derived phosphorus in surface runoff from grazed grassland lysimeters. Water Res. 31:140-148. doi:10.1016/ S0043-1354(99)80002-5

Haygarth, P.M., and S.C. Jarvis. 1999. Transfer of phosphorus from agricultural soils. Adv. Agron. 66:195-249. doi:10.1016/S0065-2113(08)60428-9 
Haygarth, P.M., and A.N. Sharpley. 2000. Terminology for phosphorus transfer. J. Environ. Qual. 29:10-15. doi:10.2134/ jeq2000.00472425002900010002x

Heathwaite, A.L., P. Griffiths, and R.J. Parkinson. 1998. Nitrogen and phosphorus in runoff from grassland with buffer strips following application of fertilizers and manures. Soil Use Manage. 14:142-148. doi:10.1111/j.1475-2743.1998.tb00140.x

Hedley, M.J., and M. McLaughlin. 2005. Reactions of phosphate fertilisers and byproducts in soil. In: J.T. Sims and A. Sharpley, editors, Phosphorus: Agriculture and the environment. ASA, CSSA, SSSA, Madison, WI. p. 181-252.

Hillel, D. 1980. Fundamentals of soil physics. Academic Press, New York.

Holford, I. 1989. Phosphate behaviour in soils. Agro Sci. 2:15-21.

Johnston, A.M., and T.W. Bruulsema. 2014. 4R nutrient stewardship for improved nutrient use efficiency. Procedia Eng. 83:365-370. doi:10.1016/j. proeng.2014.09.029

Jones, O.L., and S.M. Bromfield. 1969. Phosphorus changes during leaching and decomposition of hayed off pasture plants. Aust. J. Agric. Res. 20:653-663. doi:10.1071/AR9690653

Julian, J.P., K.M. De Beurs, B. Owsley, R.J. Davies-Colley, and A.G.E. Ausseil. 2017. River water quality changes in New Zealand over 26 years: Response to land use intensity. Hydrol. Earth Syst. Sci. 21:1149-1171. doi:10.5194/ hess-21-1149-2017

Kelley, H.W. 1983. Keeping the land alive: Soil erosion-its causes and cures. FAO Soils Bull. FAO, Rome.

King, K.W., M.R. Williams, M.L. Macrae, N.R. Fausey, J. Frankenberger, D.R. Smith, et al. 2015. Phosphorus transport in agricultural subsurface drainage: A review. J. Environ. Qual. 44:467-485. doi:10.2134/ jeq2014.04.0163

Kleinman, P.J.A., D.R. Smith, C.H. Bolster, and Z.M. Easton. 2015. Phosphorus fate, management, and modeling in artificially drained systems. J. Environ. Qual. 44:460-466. doi:10.2134/jeq2015.02.0090

Kleinman, P.J.A., M.S. Srinivasan, C.J. Dell, J.P. Schmidt, A.N. Sharpley, and R.B. Bryant. 2006. Role of rainfall intensity and hydrology in nutrient transport via surface runoff. J. Environ. Qual. 35:1248-1259. doi:10.2134/ jeq2006.0015

Lambert, M.G., B.P. Devantler, P. Nes, and P.E. Penny. 1985. Losses of nitrogen, phosphorus, and sediment in runoff from hill country under different fertiliser and grazing management regimes. N. Z. J. Agric. Res. 28:371-379. doi: $10.1080 / 00288233.1985 .10430441$

Lambie, J.M.H. 1987. Granular fertiliser composition having controlled release and process for the preparation thereof. US Patent 4,657,576. Date issued: 14 April.

Larned, S.T., T. Snelder, M.J. Unwin, and G.B. McBride. 2016. Water quality in New Zealand rivers: Current state and trends. N.Z. J. Mar. Freshwater Res. 50:389-417. doi:10.1080/00288330.2016.1150309

Lawton, K., and J.A. Vomocil. 1954. The dissolution and migration of phosphorus from granular superphosphate in some Michigan soils. Soil Sci. Soc. Am. Proc. 18:26-32. doi:10.2136/sssaj1954.03615995001800010008x

Leeper, G.W., and N.C. Uren. 1997. Soil science: An introduction. 5th ed. Melbourne Univ. Press, Melbourne, Australia.

Lehr, J.R., W.E. Brown, and E.H. Brown. 1959. Chemical behaviour of monocalcium phosphate monohydrate in soils. Soil Sci. Soc. Am. Proc. 23:3-7. doi: 10.2136/sssaj1959.03615995002300010010x

Lindsay, W.L., A.W. Frazier, and H.F. Stephenson. 1959. Nature and reactions of monocalcium phosphate monohydrate in soils: III. Studies with metastable triple point solutions. Soil Sci. Soc. Am. Proc. 23:342-345. doi:10.2136/ sssaj1959.03615995002300050012x

Lindsay, W.L., A.W. Frazier, and H.F. Stephenson. 1962. Identification of reaction products from phosphate fertilizers in soils. Soil Sci. Soc. Am. Proc. 26:446-452. doi:10.2136/sssaj1962.03615995002600050013x

Lindsay, W.L., and H.F. Stephenson. 1959a. Nature of the reactions of monocalcium phosphate monohydrate in soils: I. The solution that reacts with the soil. Soil Sci. Soc. Am. Proc. 23:12-17. doi:10.2136/ sssaj1959.03615995002300010012x

Lindsay, W.L., and H.F. Stephenson. 1959b. Nature of the reactions of monocalcium phosphate monohydrate in soils: II. Dissolution and precipitation reactions involving iron, aluminum, manganese, and calcium. Soil Sci. Soc. Am. Proc. 23:18-22. doi:10.2136/sssaj1959.03615995002300010013x

Lombi, E., M.J. McLaughlin, C. Johnston, R.D. Armstrong, and R.E. Holloway. 2004. Mobility and lability of phosphorus from granular and fluid monoammonium phosphate differs in a calcareous soil. Soil Sci. Soc. Am. J. 68:682-689. doi:10.2136/sssaj2004.6820

Lombi, E., M.J. McLaughlin, C. Johnston, R.D. Armstrong, and R.E. Holloway. 2005. Mobility, solubility and lability of fluid and granular forms of P fertiliser in calcareous and non-calcareous soils under laboratory conditions. Plant Soil 269:25-34. doi:10.1007/s11104-004-0558-z
Lombi, E., K. Scheckel, R. Armastrong, S. Forrester, J. Cutler, and D. Paterson. 2006. Speciation and distribution of phosphorus in a fertilized soil. Soil Sci. Soc. Am. J. 70:2038-2048. doi:10.2136/sssaj2006.0051

Lun, F., J. Liu, P. Ciais, T. Nesme, J. Chang, R. Wang, et al. 2018. Global and regional phosphorus budgets in agricultural systems and their implications for phosphorus-use efficiency. Earth Syst. Sci. Data 10:1-18. doi:10.5194/ essd-10-1-2018

Mansell, R.S., H.M. Selim, P. Kanchanasut, J.M. Davidson, and J.G.A. Fiskell. 1977. Experimental and simulated transport of $P$ through sandy soils. Water Resour. Res. 13:189-194. doi:10.1029/WR013i001p00189

McColl, R.H.S. 1978. Chemical runoff from pasture: The influence of fertiliser and riparian zones. N. Z. J. Mar. Freshwater Res. 12:371-380. doi:10.108 0/00288330.1978.9515764

McColl, R.H.S., and A.R. Gibson. 1979. Downslope movement of nutrient in hill pasture, Taita, New Zealand: II. Effects of season, sheep grazing, and fertiliser. N. Z. J. Agric. Res. 22:151-161. doi:10.1080/00288233.1979. 10420855

McDowell, R.W. 2010. Evaluation of two management options to improve the water quality of Lake Brunner, New Zealand. N. Z. J. Agric. Res. 53:59-69. doi: $10.1080 / 00288231003606351$

McDowell, R.W. 2012. Minimising phosphorus losses from the soil matrix. Curr. Opin. Biotechnol. 23:860-865. doi:10.1016/j.copbio.2012.03.006

McDowell, R.W. 2014. Estimating the mitigation of anthropogenic loss of phosphorus in New Zealand grassland catchments. Sci. Total Environ. 468469:1178-1186. doi:10.1016/j.scitotenv.2013.03.056

McDowell, R.W. 2015. Treatment of pasture topsoil with alum to decrease phosphorus losses in subsurface drainage. Agric. Ecosyst. Environ. 207:178182. doi:10.1016/j.agee.2015.04.017

McDowell, R.W. 2017. Does variable rate irrigation decrease nutrient leaching losses from grazed dairy farming? Soil Use Manage. 33:530-537. doi: $10.1111 /$ sum. 12363

McDowell, R.W., and W. Catto. 2005. Alternative fertilisers and management to decrease incidental phosphorus loss. Environ. Chem. Lett. 2:169-174. doi:10.1007/s10311-005-0099-6

McDowell, R.W., N. Cox, C.J. Daughney, D. Wheeler, and M. Moreau. 2015. A national assessment of the potential linkage between soil, and surface and groundwater concentrations of phosphorus. J. Am. Water Resour. Assoc. 51:992-1002. doi:10.1111/1752-1688.12337

McDowell, R.W., M.J. Hedley, R. Pletnyakov, C. Rissman, W. Catto and W. Patrick. 2019. Why are median phosphorus concentrations improving in New Zealand streams and rivers? J. R. Soc. N. Z. 49.

McDowell, R.W., S.T. Larned, and D.J. Houlbrooke. 2009a. Nitrogen and phosphorus in New Zealand streams and rivers: Control and impact of eutrophication and the influence of land management. N.Z. J. Mar. Freshwater Res. 43:985-995. doi:10.1080/00288330909510055

McDowell, R.W., R.P. Littlejohn, and J.D. Blennerhassett. 2010. Phosphorus fertilizer form affects phosphorus loss to waterways: A paired catchment study. Soil Use Manage. 26:365-373. doi:10.1111/j.1475-2743.2010.00289.x

McDowell, R.W., and R.M. Monaghan. 2015. Extreme phosphorus losses in drainage from grazed dairy pastures on marginal land. J. Environ. Qual. 44:545-551. doi:10.2134/jeq2014.04.0160

McDowell, R.W., R.M. Monaghan, and P.L. Carey. 2003. Potential phosphorus losses in overland flow from pastoral soils receiving long-term applications of either superphosphate or reactive phosphate rock. N. Z. J. Agric. Res. 46:329-337. doi:10.1080/00288233.2003.9513561

McDowell, R.W., and D.M. Nash. 2012. A review of the cost-effectiveness and suitability of mitigation strategies to prevent phosphorus loss from dairy farms in New Zealand and Australia. J. Environ. Qual. 41:680-693. doi:10.2134/jeq2011.0041

McDowell, R., D. Nash, A. George, Q.J. Wang, and R. Duncan. 2009b. Approaches for quantifying and managing diffuse phosphorus $(\mathrm{P})$ exports at the farm/sub catchment scale. J. Environ. Qual. 38:1968-1980. doi:10.2134/jeq2007.0651

McDowell, R.W., D.M. Nash, and F. Robertson. 2007. Sources of phosphorus lost from a grazed pasture receiving simulated rainfall. J. Environ. Qual. 36:1281-1288. doi: $10.2134 /$ jeq2006.0347

McDowell, R.W., T.H. Snelder, and N. Cox. 2013a. Establishment of reference conditions and trigger values for chemical, physical, and micro-biological indicators in New Zealand streams and rivers. Ag Research, Lincoln, Christchurch, New Zealand.

McDowell, R.W., T.H. Snelder, N. Cox, D.J. Booker, and R.J. Wilcock. 2013b. Establishment of reference or baseline conditions of chemical indicators in New Zealand streams and rivers relative to present conditions. Mar. Freshwater Res. 64:387-400. doi:10.1071/MF12153

Meat and Livestock Australia. 2017. Livestock distribution maps. Meat and Livestock Australia, Canberra, ACT, Australia. 
Miltner, R.J. 2010. A method and rationale for deriving nutrient criteria for small rivers and streams in Ohio. Environ. Manage. 45:842-855. doi:10.1007/ s00267-010-9439-9

Monaghan, R.M., R.J. Paton, and J.J. Drewry. 2002. Nitrogen and phosphorus losses in mole and tile drainage from a cattle-grazed pasture in eastern Southland. N. Z. J. Agric. Res. 45:197-205. doi:10.1080/00288233.200 2.9513510

Monaghan, R.M., L.C. Smith, and R.W. Muirhead. 2016. Pathways of contaminant transfers to water from an artificially-drained soil under intensive grazing by dairy cows. Agric. Ecosyst. Environ. 220:76-88. doi:10.1016/j. agee.2015.12.024

Moody, P.W., D.G. Edwards, and L.C. Bell. 1995. Effect of banded fertiliser on soil solution composition and short-term root growth: II. Mono- and di-ammonium phosphates. Aust. J. Soil Res. 33:689-707. doi:10.1071/ SR9950689

Moore, I.D., and G.R. Foster. 1990. Hydraulics and overland flow. In: Process studies in hillslope hydrology. John Wiley \& Sons, Chichester, UK. p. 215-254.

Morgan, K.T., K.E. Cushman, and S. Sato. 2009. Release mechanisms for slowand controlled-release fertilizers and strategies for their use in vegetable production. HortTechnology 19:10-12. doi:10.21273/HORTSCI.19.1.10

Mundy, G.N., K.J. Nexhip, N.R. Austin, and M.D. Collins. 2003. The influence of cutting and grazing on phosphorus and nitrogen in irrigation runoff from perennial pasture. Aust. J. Soil Res. 41:675-685. doi:10.1071/ SR02087

Murphy, J., and J.P. Riley. 1962. A modified single solution method for the determination of phosphate in natural waters. Anal. Chim. Acta 27:31-36. doi:10.1016/S0003-2670(00)88444-5

Nash, D., and K. Barlow. 2009. Impacts of irrigated dairying on the environment. In: R. McDowell, editor, Impacts of pastoral grazing on the environment. CAB International, Wallingford, UK. p. 232-248.

Nash, D., L. Clemow, M. Hannah, K. Barlow, and P. Gangaiya. 2005. Modelling phosphorus exports from rain-fed and irrigated pastures in southern Australia. Aust. J. Soil Res. 43:745-755. doi:10.1071/SR04119

Nash, D.M., and D. Halliwell. 1999. Fertilisers and phosphorus loss from productive grazing systems. Aust. J. Soil Res. 37:403-429. doi:10.1071/S98087

Nash, D.M., D. Halliwell, and J. Cox. 2002. Hydrological mobilisation of pollutants at the slope/field scale. In: P.M. Haygarth and S.C. Jarvis, editors, Agriculture, hydrology, and water quality. CABI Publishing, Oxon, UK. p. 225-242. doi:10.1079/9780851995458.0225

Nash, D., and M. Hannah. 2011. Using Monte-Carlo simulations and Bayesian Networks to quantify and demonstrate the impact of fertiliser best management practices. Environ. Model. Softw. 26:1079-1088. doi:10.1016/j. envsoft.2011.03.009

Nash, D.M., M. Hannah, L. Clemow, D. Halliwell, B.J. Webb, and D. Chapman. 2003. A laboratory study of phosphorus mobilisation from commercial fertilisers. Aust. J. Soil Res. 41:1201-1212. doi:10.1071/SR03024

Nash, D.M., M. Hannah, L. Clemow, D. Halliwell, B.J. Webb, and D. Chapman. 2004. A field study of phosphorus mobilisation from commercial fertilisers. Aust. J. Soil Res. 42:313-320. doi:10.1071/SR03062

Nash, D., M. Hannah, D. Halliwell, and C. Murdoch. 2000. Factors affecting phosphorus export from a pasture-based grazing system. J. Environ. Qual. 29:1160-1166. doi:10.2134/jeq2000.00472425002900040017x

Nash, D.M., P.M. Haygarth, B.L. Turner, L.M. Condron, R.W. McDowell, A.E. Richardson, et al. 2014. Using organic phosphorus to sustain pasture productivity: A perspective. Geoderma 221-222:11-19. doi:10.1016/j. geoderma.2013.12.004

Nash, D., and C. Murdoch. 1997. Phosphorus in runoff from a fertile dairy pasture. Aust. J. Soil Res. 35:419-429. doi:10.1071/S96039

Nash, D., B. Webb, M. Hannah, S. Adeloju, M. Toifl, K. Barlow, et al. 2007. Changes in nitrogen and phosphorus concentrations in soil, soil water, and surface run-off following grading of irrigation bays used for intensive grazing. Soil Use Manage. 23:374-383. doi:10.1111/j.1475-2743.2007.00100.x

Nexhip, K.J., G.N. Mundy, M.D. Collins, and N.R. Austin. 1997. Development of nutrient water quality targets for irrigated pasture sub-catchments. Department of Natural Resources and Environment, Institute of Sustainable Irrigated Agriculture, Tatura, Australia.

New Zealand Government. 2017. National policy statement for freshwater management 2014 (amended 2017). Ministry for the Environment, New Zealand Government, Wellington, New Zealand.

Nichols, D.J., T.C. Daniel, and D.R. Edwards. 1994. Nutrient runoff from pasture after incorporation of poultry litter or inorganic fertilizer. Soil Sci. Soc. Am. J. 58:1224-1228. doi:10.2136/sssaj1994.03615995005800040032x

Noack, S.R., M.J. McLaughlin, R.J. Smernik, T.M. McBeath, and R.D. Armstrong. 2012. Crop residue phosphorus: Speciation and potential bioavailability. Plant Soil 359:375-385. doi:10.1007/s11104-012-1216-5
Olness, A.E., E.D. Rhoades, S.J. Smith, and R.G. Menzel. 1980. Fertilizer nutrient losses from rangeland watersheds in central Oklahoma. J. Environ. Qual. 9:81-86. doi:10.2134/jeq1980.00472425000900010019x

Owens, L.B., and M.J. Shipitalo. 2006. Surface and subsurface phosphorus losses from fertilized pasture systems in Ohio. J. Environ. Qual. 35:1101-1109. doi:10.2134/jeq2005.0402

Ozanne, P.G., D.J. Kirkton, and T.C. Shaw. 1961. The loss of P from sandy soils. Aust. J. Agric. Res. 12:409-423. doi:10.1071/AR9610409

Payne, D. 1988. The behaviour of water in soil. In: A. Wild, editor, Russell's soil conditions and plant growth. Longman Scientific and Technical Publishing, Avon, UK. p. 315-337.

Pierson, S.T., M.L. Cabrera, G.K. Evanylo, H.A. Kuykendall, C.S. Hoveland, M.A. McCann, et al. 2001. Phosphorus and ammonium concentrations in surface runoff from grasslands fertilized with broiler litter. J. Environ. Qual. 30:1784-1789. doi:10.2134/jeq2001.3051784x

Pierzynski, G.M., R. McDowell, and J.T. Sims. 2005. Chemistry, cycling, and potential movement of inorganic phosphorus in soils. In: J.T. Sims and A. Sharpley, editors, Phosphorus: Agriculture and the environment. ASA, CSSA, SSSA, Madison, WI. p. 53-86.

Pote, D.H., W.L. Kingery, G.E. Aiken, F.X. Han, and P.A. Moore, Jr. 2006. Incorporating granular inorganic fertilizer into perennial grassland soils to improve water quality. J. Soil Water Conserv. 61:1-7.

Preedy, N., K. McTiernan, R. Matthews, L. Heathwaite, and P. Haygarth. 2001. Rapid incidental phosphorus transfers from grassland. J. Environ. Qual. 30:2105-2112. doi: 10.2134/jeq2001.2105

PricewaterhouseCoopers. 2011. The Australian dairy industry: The basics. PricewaterhouseCoopers International, Melbourne, VIC, Australia.

Quin, B.F., M.R. Hart, J.D. Blennerhassett, and L. Wedderburn. 2004. Phosphorus loss. N. Z. J. Agric. Res. 47:105-108. doi:10.1080/00288233.2004.9 513577

Robinson, J.S., A.N. Sharpley, and S.J. Smith. 1994. Development of a method to determine bioavailable phosphorus loss in agricultural runoff. Agric. Ecosyst. Environ. 47:287-297. doi:10.1016/0167-8809(94)90095-7

Rulon, J., R. Rodway, and A. Freeze. 1985. The development of multiple seepage faces on layered slopes. Water Resour. Res. 21:1625-1636. doi:10.1029/ WR021i011p01625

Sale, P.W.G., A. Brown, G. Maclaren, P.K. Derbyshire, and S.M. Veitch. 1997a. Pasture environments in Australia where reactive phosphate rock will be an effective phosphate fertiliser. Aust. J. Exp. Agric. 37:1051-1060. doi:10.1071/EA96119

Sale, P.W.G., P.G. Simpson, D.C. Lewis, R.J. Gilkes, M.A. Bolland, D.A. Ratkowsky, et al. 1997b. The agronomic effectiveness of reactive phosphate rocks: 1. Effect of the pasture environment. Aust. J. Exp. Agric. 37:921936. doi:10.1071/EA96108

Sample, E.C., F.E. Khasawneh, and I. Hashimoto. 1979. Reactions of ammonium ortho- and polyphosphate fertilizers in soil: III. Effects of associated cations. Soil Sci. Soc. Am. J. 43:58-65. doi:10.2136/ sssaj1979.03615995004300010010x

Sample, E.C., R.J. Soper, and G.J. Racz. 1980. Reactions of phosphate fertilizers in soils. In: F.E. Khasawneh, E.C. Sample, and E.J. Kamprath, editors, The role of phosphorus in agriculture. ASA, Madison, WI. p. 263-310.

Shainberg, I., J.M. Laflen, J.M. Bradford, and L.D. Norton. 1994. Hydraulic flow and water characteristics in rill erosion. Soil Sci. Soc. Am. J. 58:1007-1012. doi:10.2136/sssaj1994.03615995005800040002x

Sharpley, A.N. 1980. The enrichment of soil phosphorus in runoff sediments. J. Environ. Qual. 9:521-526. doi:10.2134/ jeq1980.00472425000900030039x

Sharpley, A.N. 1981. The contribution of phosphorus leached from crop canopy to losses in surface runoff. J. Environ. Qual. 10:160-165. doi:10.2134/ jeq1981.00472425001000020007x

Sharpley, A.N. 1985. The selective erosion of plant nutrients in runoff. Soil Sci.Soc. Am. J. 49:1527-1534. doi:10.2136/sssaj1985.03615995004900060039x

Sharpley, A., S. Chapra, R. Wedepohl, J. Sims, T. Daniel, and K. Reddy. 1994. Managing agricultural phosphorus for protection of surface waters: Issues and options. J. Environ. Qual. 23:437-451. doi:10.2134/ jeq1994.00472425002300030006x

Sharpley, A.N., H.P. Jarvie, D.N. Flaten, and P.J.A. Kleinman. 2018. Celebrating the 350th anniversary of phosphorus discovery: A conundrum of deficiency and excess. J. Environ. Qual. 47:774-777. doi:10.2134/ jeq2018.05.0170

Sharpley, A.N., and J.K. Syers. 1979. Effect of aerial topdressing with superphosphate on the loss of phosphate from a pasture catchment. N. Z. J. Agric. Res. 22:273-277. doi:10.1080/00288233.1979.10430747

Sharpley, A.N., and J.K. Syers. 1983. Transport of phosphorus in surface runoff as influenced by liquid and solid fertilizer phosphate addition. Water Air Soil Pollut. 19:321-326. 
Shaviv, A., and R.L. Mikkelsen. 1993. Controlled-release fertilizers to increase efficiency of nutrient use and minimize environmental degradation: A review. Fert. Res. 35:1-12. doi:10.1007/BF00750215

Shi, X.-Z., L. Wu, W. Weiping, and Q. Wang. 2011. Solute transfer from the soil surface: A review. Soil Sci. Soc. Am. J. 75:1214-1225. doi:10.2136/ sssaj2010.0433

Shigaki, F., A.N. Sharpley, and L.I. Prochnow. 2006. Source-related transport of phosphorus in surface runoff. J. Environ. Qual. 35:2229-2235. doi: $10.2134 /$ jeq2006.0112

Shigaki, F., A. Sharpley, and L.I. Prochnow. 2007. Rainfall intensity and phosphorus source effects on phosphorus transport in surface runoff from soil trays. Sci. Total Environ. 373:334-343. doi:10.1016/j.scitotenv.2006.10.048

Simmonds, B., R.W. McDowell, and L.M. Condron. 2017. The effect of soil moisture extremes on the pathways and forms of phosphorus lost in runoff from two contrasting soil types. Soil Res. 55:19-27. doi:10.1071/ SR15324

Simmonds, B., R.W. McDowell, L.M. Condron, and N. Cox. 2016. Can phosphorus fertilizers sparingly soluble in water decrease phosphorus leaching loss from an acid peat soil? Soil Use Manage. 32:322-328. doi:10.1111/ sum. 12274

Simmonds, B.M., R.W. McDowell, L.M. Condron, and T. Jowett. 2015. Potential phosphorus losses from organic and podzol soils: Prediction and the influence of soil physico-chemical properties and management. N. Z. J. Agric. Res. 58:170-180. doi:10.1080/00288233.2014.988830

Simpson, P.G., P.W.G. Sale, and S.B. Tennakoon. 1997. An economic analysis of the field performance on North Carolina reactive phosphate rock compared with single superphosphate for selected sites from the National Reactive Phosphate Rock Project. Aust. J. Exp. Agric. 37:1061-1076. doi:10.1071/EA96120

Sinclair, A.G., C.B. Dyson, and P.W. Shannon. 1990. The long-term effectiveness of reactive phosphate rock as a phosphate fertiliser for New Zealand pastures. Proc. N. Z. Grassl. Assoc. 51:101-104.

Sinclair Knight Merz. 2011. National water quality assessment 2011. State of the Environment 2011 Committee, Australian Government Department of Sustainability, Environment, Water, Population and Communities, Canberra, ACT.

Smith, A.J., and C.P. Tran. 2010. A weight-of-evidence approach to define nutrient criteria protective of aquatic life in large rivers. J. North Am. Benthol. Soc. 29:875-891. doi:10.1899/09-076.1

Smith, D.D., and W.H. Wischmeier. 1962. Rainfall erosion. Adv. Agron. 14:109-148. doi:10.1016/S0065-2113(08)60437-X

Smith, D.R., R.D. Harmel, M. Williams, R. Haney, and K.W. King. 2016. Managing acute phosphorus loss with fertilizer source and placement: Proof of concept. Agric. Environ. Lett. 1:150015. doi:10.2134/ael2015.12.0015

Snyder, J.K., and D.A. Woolhiser. 1985. Effects of infiltration on chemical transport into overland flow. Trans. ASAE 28:1450-1457. doi:10.13031/2013.32459

Steenhuis, T.S., H.M. Van Es, J.Y. Parlange, P.C. Baveye, M.F. Walter, L.D. Geohring, et al. 1990. Hydrology and the environment. N. Y. Food Life Sci. Q. 20:15-19.

Stephen, R., and L. Condron. 1986. An assessment of the agronomic efficiency of partially acidulated phosphate rock fertilisers. Fert. Res. 10:269-282. doi:10.1007/BF01049357

Stevenson, R.J., B.H. Hill, A.T. Herlihy, L.L. Yuan, and S.B. Norton. 2008. Algae-P relationships, thresholds, and frequency distributions guide nutrient criterion development. J. North Am. Benthol. Soc. 27:783-799. doi:10.1899/07-077.1

Stutter, M.I., C.A. Shand, T.S. George, M.S.A. Blackwell, L. Dixon, R. Bol, et al. 2015. Land use and soil factors affecting accumulation of phosphorus species in temperate soils. Geoderma 257-258:29-39. doi:10.1016/j. geoderma.2015.03.020

Tarkalson, D.D., and R.L. Mikkelsen. 2004. Runoff phosphorus losses as related to phosphorus source, application method, and application rate on a piedmont soil. J. Environ. Qual. 33:1424-1430. doi:10.2134/jeq2004.1424

Tian, J., G. Boitt, A. Black, S. Wakelin, L.M. Condron, and L. Chen. 2017. Accumulation and distribution of phosphorus in the soil profile under fertilized grazed pasture. Agric. Ecosyst. Environ. 239:228-235. doi:10.1016/j. agee.2017.01.022
Toifl, M., D. Halliwell, D. Nash, F. Roddick, N. Porter, and B. Meehan. 2000. Soil solution P concentrations: An effective predictive tool for predicting P exports from irrigated grazing systems? In: J. A. Adams and A. K. Metherell, editors, Soil 2000: New horizons for a new century. Australian and New Zealand Second Joint Soils Conference. New Zealand Society of Soil Science, Lincoln University, New Zealand.

Toor, G.S., L.M. Condron, H.J. Di, K.C. Cameron, and B.J. Cade-Menun. 2003. Characterization of organic phosphorus in leachate from a grassland soil. Soil Biol. Biochem. 35:1317-1323. doi:10.1016/S0038-0717(03)00202-5

Turral, H., M. Wood, and C. Fitzpatrick. 2017. Macalister land and water management plan review. West Gippsland Catchment Management Authority, Traralgon, VIC, Australia.

Umesha, C., C.J. Sridhara, and A.H. Kumarnarnaik. 2017. Recent forms of fertilizers and their use to improve nutrient use efficiency and to minimize environmental impacts. Int. J. Pure Appl. Biosci. 5:858-863. doi:10.18782/2320-7051.2739

USEPA. 1996. Environmental indicators of water quality in the United States. USEPA, Office of Water, Washington, DC.

Vadas, P.A., D.L. Busch, J. Powell, and G.E. Brink. 2015. Monitoring runoff from cattle-grazed pastures for a phosphorus loss quantification tool. Agric. Ecosyst. Environ. 199:124-131. doi:10.1016/j.agee.2014.08.026

Vadas, P.A., L.B. Owens, and A.N. Sharpley. 2008. An empirical model for dissolved phosphorus in runoff from surface-applied fertilizers. Agric. Ecosyst. Environ. 127:59-65. doi:10.1016/j.agee.2008.03.001

Walton, C.P., and G.F. Lee. 1972. A biological evaluation of the molybdenum blue method for orthophosphate analysis. SIL Proc. 1922-2010 18:676684. doi:10.1080/03680770.1972.11899524

Watkins, M., H. Castlehouse, M. Hannah, and D.M. Nash. 2012. Nitrogen and phosphorus changes in soil and soil water after cultivation. Appl. Environ. Soil Sci. 10. doi: $10.1155 / 2012 / 157068$

Weaver, D.M., G.S.P. Ritchie, and G.C. Anderson. 1988a. Phosphorus leaching in sandy soils: II. Laboratory studies of the long-term effects of the phosphorus source. Aust. J. Soil Res. 26:191-200. doi:10.1071/SR9880191

Weaver, D.M., G.S.P. Ritchie, G.C. Anderson, and D.M. Deeley. 1988b. Phosphorus leaching in sandy soils: I. Short-term effects of fertiliser applications and environmental conditions. Aust. J. Soil Res. 26:177-190. doi:10.1071/SR9880177

Webster, I.T., J.S. Parslow, R. Grayson, R.P. Molloy, J. Andrewartha, P. Sakov, et al. 2001. Gippsland Lakes environmental study: Assessing options for improving water quality and ecological function. CSIRO, Glen Osmond, Australia.

Wheeler, D., and D. Edmeades. 1995. Effect of depth and lime or phosphorusfertilizer applications on the soil solution chemistry of some New Zealand pastoral soils. Soil Res. 33:461-476. doi:10.1071/SR9950461

Wilcock, B., B. Biggs, R. Death, C. Hickey, S. Larned, and J. Quinn. 2007. Limiting nutrients for controlling undesirable periphyton growth. NIWA Client Report HAM2007-006. NIWA Project ELF07202. National Institute for Water and Atmospheric Research, Hamilton, New Zealand.

Williams, A.G., J.F. Dowd, D. Scholefield, N.M. Holden, and L.K. Deeks. 2003. Preferential flow variability in a well-structured soil. Soil Sci. Soc. Am. J. 67:1272-1281. doi:10.2136/sssaj2003.1272

Williams, C. 1971a. Reaction of surface-applied superphosphate with soil: I. The fertilizer solution and its initial reaction with soil. Soil Res. 9:83-94. doi:10.1071/SR9710083

Williams, C. 1971b. Reaction of surface-applied superphosphate with soil: II. Movement of the phosphorus and sulphur into the soil. Soil Res. 9:95106. doi:10.1071/SR9710095

Williams, C.H. 1969. Moisture uptake by surface-applied superphosphate and movement of the phosphate and sulphate into the soil. Aust. J. Soil Res. 7:307-316. doi:10.1071/SR9690307

Williams, M.R., K.W. King, W. Ford, A.R. Buda, and C.D. Kennedy. 2016. Effect of tillage on macropore flow and phosphorus transport to tile drains. Water Resour. Res. 52:2868-2882. doi:10.1002/2015WR017650

Wischmeier, W.H., and D.D. Smith. 1978. Predicting soil erosion losses: A guide to conservation planning. Agric. Handb. 537. USDA, Washington, DC. p. 4522-4561.

Yeates, J.S., and M.F. Clarke. 1993. Developing alternatives to fertilizers of high water solubility. Fert. Res. 36:141-150. doi:10.1007/BF00747585 